\title{
Benefits of utilizing on-site and off-site renewable energy sources for the single family detached house
}

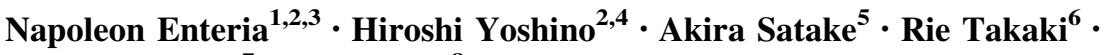 \\ Hideki Ishihara $^{7} \cdot$ Seizo Baba $^{8}$
}

Received: 29 April 2015/ Accepted: 15 February 2016/Published online: 29 February 2016

(C) The Author(s) 2016. This article is published with open access at Springerlink.com

\begin{abstract}
Japanese Government is formulating new energy policies in the utilization of alternative energy sources to reduce reliance on nuclear and fossil-powered energy sources. This study shows the numerical evaluation of utilizing alternative energy sources for the demonstration single family detached house. The study shows that utilization of different alternative energy sources both offsite and on-site could reduce the house's dependency on grid line electricity and fossil fuel. The installation of photovoltaic roof tiles, excess generated electricity could be sold through the feed-in tariff scheme. The utilization of a biomass fuel water heater could reduce the carbon dioxide emission. The combination of photovoltaic roof tiles and solar thermal collector with biomass fueled water heater allows the house to sell excess electricity produced, and eliminates the carbon dioxide emission.
\end{abstract}

Keywords Economics $\cdot$ Environment $\cdot$ Renewable energy $\cdot$ Energy conservation $\cdot$ Detached house

\section{Napoleon Enteria}

enterian2@asme.org; napoleon@kenken.go.jp;

nenteria@yahoo.com

Building Research Institute, Tsukuba 305-0802, Japan

Tohoku University, Sendai 980-8579, Japan

Enteria Grün Energietechnik, 8000 Davao, Philippines

Architectural Institute of Japan, Tokyo 108-8414, Japan

5 Maeda Corporation, Tokyo 179-8914, Japan

6 Akita Prefectural University, Akita 010-0195, Japan

7 Hokushu House Company, Ltd., Tomiya 981-3341, Japan

8 Earth Clean Tohoku Co., Ltd, Sendai 980-8579, Japan

\section{Nomenclature}

\section{List of symbols}

A Solar collector area $\left(\mathrm{m}^{2}\right)$

AC Air cooler

BA Back-up heater

$\dot{c}_{\text {Aux }} \quad$ Fuel cost $(\$ / \mathrm{kg})$

$C_{P} \quad$ Specific heat $(\mathrm{kJ} / \mathrm{kg}-\mathrm{K})$

$\dot{C}_{\text {Aux }} \quad$ Energy cost (\$)

$E \quad$ Electric energy (kWh)

$\dot{E} \quad$ Electric power $(\mathrm{kW})$

$\dot{Q}$ Thermal power $(\mathrm{kW})$

$Q \quad$ Thermal energy (kWh)

$h \quad$ Moist air enthalpy $(\mathrm{kJ} / \mathrm{kg})$

$I_{R} \quad$ Solar irradiance $\left(\mathrm{kW} / \mathrm{m}^{2}\right)$

$\dot{m} \quad$ Mass flow $(\mathrm{kg} / \mathrm{s})$

$t \quad$ Time (s)

$T$ Temperature $\left({ }^{\circ} \mathrm{C}\right)$

$\mathrm{CO}_{2} \quad$ Carbon dioxide

COP Coefficient of performance

d Day

DHW Domestic hot water

EA Exit air

EC Evaporative cooler

LHV Low heating value $(\mathrm{kW} / \mathrm{kg})$

PV Photovoltaic

SA Supply air

STF Solar thermal fraction

SEF Solar electric fraction

\section{Acronyms}

AMeDAS Automated Meteorological Data Acquisition System

CFL Compact fluorescent lamp 


$\begin{array}{ll}\text { EER } & \text { Energy efficiency ratio } \\ \text { EEH } & \text { Energy efficient home } \\ \text { EGH } & \text { Energy generating home } \\ \text { EPH } & \text { Energy plus home } \\ \text { FIT } & \text { Feed-in tariff } \\ \text { LED } & \text { Light emitting diode } \\ \text { HVAC } & \text { Heating, ventilating and air-conditioning } \\ & \text { system } \\ \text { JMA } & \text { Japan Meteorological Agency } \\ \text { NCEH } & \text { Negative carbon emission home } \\ \text { LCCM } & \text { Life cycle carbon minus } \\ \text { TESS } & \text { Thermal Energy System Specialists } \\ \text { TRNSYS } & \text { Transient System Simulation } \\ \text { ZEH } & \text { Zero emission house }\end{array}$

Symbols

$\eta \quad$ Efficiency

\section{Subscripts}

1,2

HVAC system notation

$a, b \quad$ Thermal system notation

APP Appliances

Aux Auxiliary thermal/electric energy

CE Cooling effect

CL Cooling load

EC Electric consumption

F Fuel

GL Grid line electricity

HC Heating coil

HL Heating load

HVAC Heating, ventilating and air-conditioning system

HW Hot water

I Inverter

PV Photovoltaic

PP Photovoltaic panel

SA Supply air

SC Solar collector

SE Solar thermal energy, sensible energy

TE Thermal energy

W Water

\section{Introduction}

In Japan, a new energy policy was implemented in which renewable energy resources are given a large slice of the contribution in energy sources [1]. In addition, there is a government plan to eliminate nuclear power sources by 2030 [2]. In this situation, utilization and development of alternative energy sources such as renewable energy sources is important. Furthermore, energy conservation and efficiency through application of new technologies will cater to the utilization of alternative energy sources [3]. As buildings are one of the main energy users [4], one of the main focuses of renewable energy application, conservation and efficiency implementations are in the building sector [5].

In other countries, particularly in Germany, it was demonstrated that the utilization of different renewable energy sources along with the application of new technologies can make even a whole town energy independent [6]. The Solar Decathlon contest [7] is aimed at developing a house which can itself generate its own energy requirement, by applying the different studies of an energy efficient home (EEH), energy plus home (EPH), zero emission house (ZEH) and others. Also, in Japan, there is a project for the life cycle carbon minus (LCCM) house [8]. The main objective of all these projects is to implement a practical building/house concept and technologies which can be commercialized.

In residential buildings, energy conservation through the application of high performance envelopes [9, 10], ventilation [11, 12], energy efficient lighting [13] and appliances [14] is becoming common in developed countries such as Japan $[4,15]$. In some residential buildings, installation of non-conventional energy utilization devices such as solar thermal collector [16], photovoltaic panels [17] and even wind turbines [18] have been done.

The development of the energy generating home (EGH) in the utilization of both on-site and off-site renewable energy such as sources from solar energy, low grade geothermal energy, wind energy and biomass [19]. Through the feed-in tariff (FIT) mechanism, the excess electricity generated by the home can be sold [20], thus reducing carbon dioxide emission in electricity generation for the grid line. In Japan, the feed-in tariff law was just implemented in July 2012 [1]. With the country's new energy policy of renewable energy utilization with the goal of eliminating of nuclear energy sources [2], it is expected that utilization of renewable energy sources for the building sector will increase.

Therefore, investigation of the utilization of different sources of renewable energy for residential building is important so that we can understand its viability and feasibility in terms of on-site and off-site available energy sources, house technologies that could be used and developed to support the different energy sources, and application of laws governing the utilization of energy generation $[21,22]$. Taking this situation into account, long term investigation through numerical evaluation is needed.

This paper shows the numerical investigation and evaluation of the single family detached house with the scenario for the utilization of different sources of renewable energy, implementation of new technologies based on the Japan new energy policy and the feed-in tariff mechanism. It is highlighted in this paper that desiccant-based 
air-conditioning system is primarily utilized as compared to previous research works for the energy efficient houses which utilizes typical air-conditioning systems [8, 23, 24]. The objective of this paper is to show the operational economic and environmental benefits of using alternative and renewable energy sources, and at the same time, the application of the new technologies coupled with these renewable energy sources. It is wort to mention at this stage of evaluation that investment cost is not considered in the economic analysis as the system is subject for field evaluation, actual analysis, equipment optimization and system evaluation.

\section{Methodology}

\section{House and system description}

This demonstration house is located in the company vicinity just inside the town of Tomiya, at the boundary of Sendai City $\left(38.2667^{\circ} \mathrm{N}, 140.8667^{\circ} \mathrm{E}\right)$. The house comprises one floor of basement for the guest room, stock room, and guest toilet and shower $\left(79.50 \mathrm{~m}^{2}\right.$ floor area). The first floor is for the living room, dining room, kitchen and toilet $\left(79.50 \mathrm{~m}^{2}\right.$ floor area plus $14.91 \mathrm{~m}^{2}$ winter garden area). The second floor is for the master bedroom, children's room and for the toilet, shower and tub $\left(79.50 \mathrm{~m}^{2}\right.$ floor area) as shown in Fig. 1.
Figure 2a shows the house floor plan, floor and external wall construction and the diagram of the total energy system coupled to the house. The house comprises 1 floor of basement for the guest room, stock room, and guest toilet and shower, and the first floor for the living room, dining room, kitchen and toilet and winter garden area. The second floor is for the master bedroom, children's room and for the toilet, shower and tub. Figure $2 b$ shows the shows the schematic diagram of the whole system which comprises the thermal system, electric system and the desiccant-based heating, ventilating and air-conditioning systems. The desiccant-based HVAC system utilizes the heat from the solar energy and back-up water heater to support air-heating during winter time and hot water production. It is also used for desiccant regeneration during summer time. The ground borehole heat exchanger serves as back-up air cooler during summer time. The HVAC system has a maximum volumetric air flow rate of $340 \mathrm{~m}^{3} / \mathrm{h}$ which provides $30 \%$ for the dining room, $30 \%$ for the living room and $40 \%$ for the children's and master bedrooms. The HVAC air flow rate is metered according to the occupancy of the rooms. Each of the rooms shown in Fig. 1 such as living room, dining room, corridors, masters bedroom, child rooms, has supply and return air ducts for the HVAC system.

Table 1 shows the single family detached house building envelope thermal properties. Based on the table, it shows that the construction method and materials used are
Fig. 1 Actual view of the model and demonstration single family detached house: a house perspective; b photovoltaic roofing tiles; c flat place solar collector; d desiccant-based heating, ventilating and airconditioning system
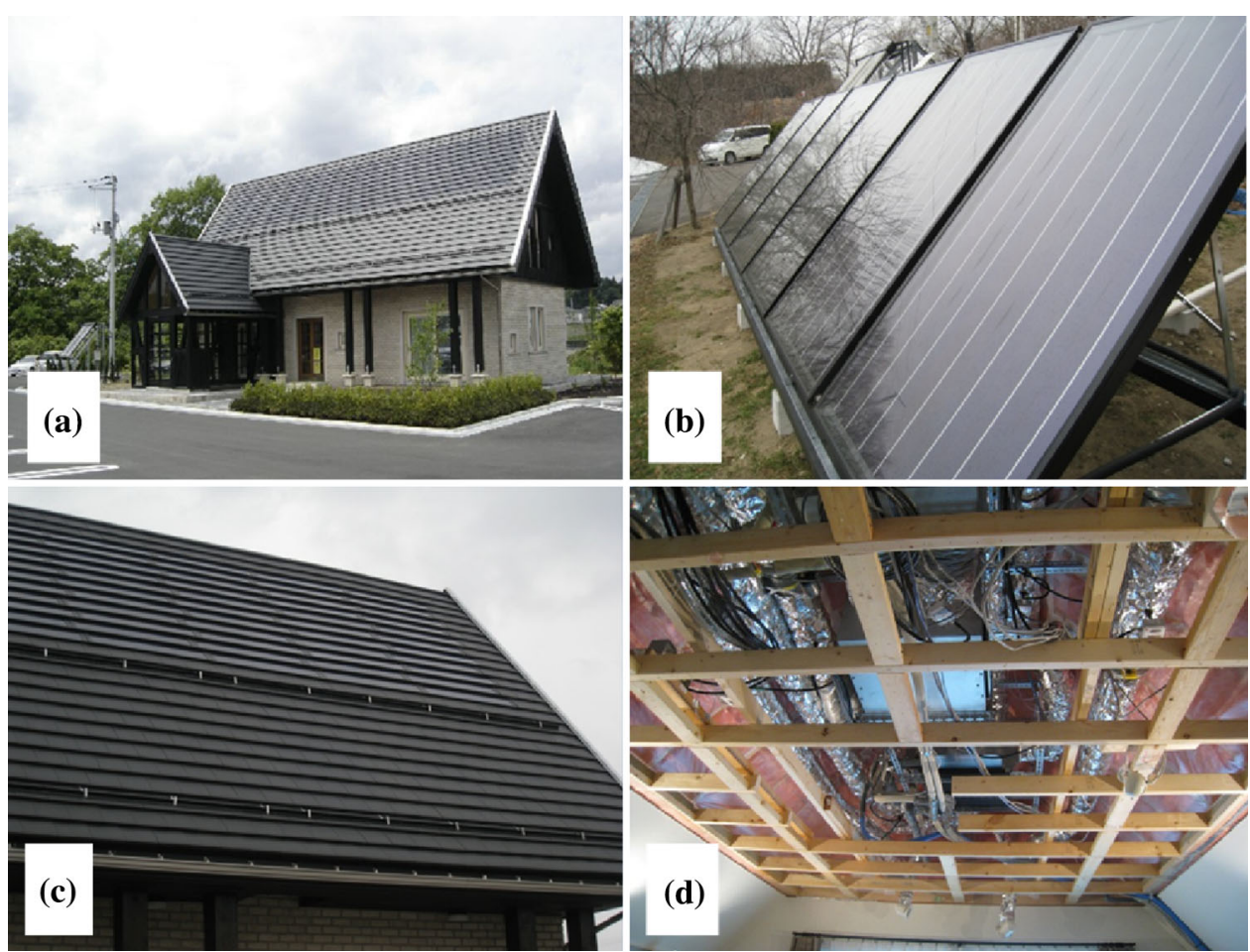

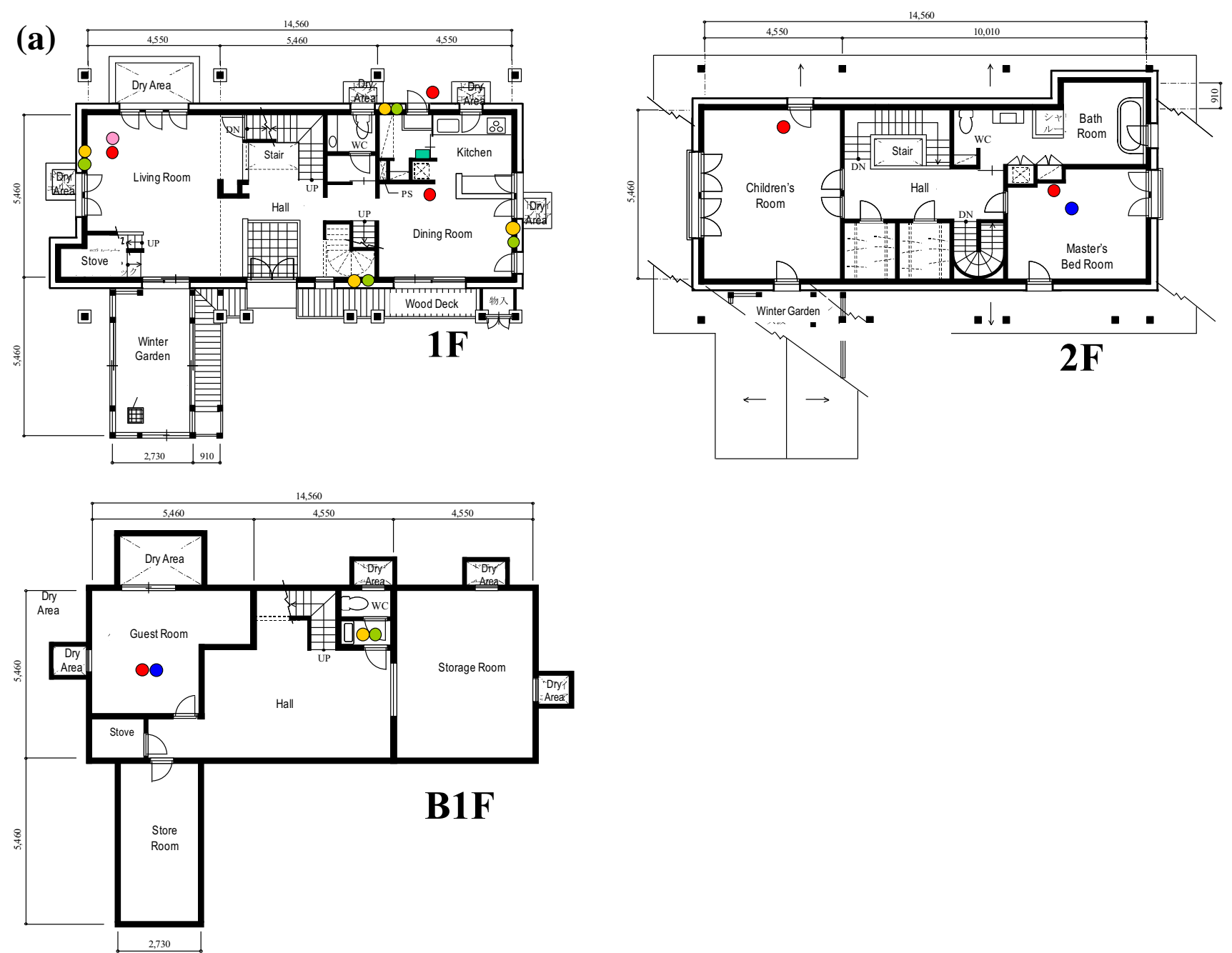

Fig. 2 Schematic diagram: a model and demonstration house floor plans, and $\mathbf{b}$ house and system

superior to those of the typical detached house, which means that the house is well-insulated so as to conserve energy. Also, as shown on the rooftop, photovoltaic roof tiles are used. The advantage of the photovoltaic roof tiles compared to photovoltaic modules is the elimination of multiple layers of roof materials, thus, minimizing cost and at the same time enhancing its aesthetic view.

\section{House and system operation}

Figure 3 shows the occupancy time schedule for the single family house based on the weekdays, weekends and holidays. The developed occupancy period is based on the investigation of the occupancy model presented by Yamaguchi et al. [25]. This occupancy model is based on four occupants-father, mother and two children. During weekdays, the father will go to work, the two children will go to school and only the mother will be in the house. Figure 4 shows the estimated house lighting and lighting wattage schedule. The estimated house lighting schedule is based on the occupancy time schedule. The lighting is compact fluorescent lamp (CFL) in the first floor and light emitting diode (LED) in the first floor.

\section{First floor lighting}

- Living areas: two 13 wattage and four 6.9 wattage; two 6.4 wattage are located in the stairs.

- Dining areas: seven 12 wattage (dining hall), one 13 wattage (dining area) and one 6.4 wattage (counter).

\section{Second floor lighting}

- Children's room: eight 60 wattage.

- Hall: two 120 wattage.

- Stairs: three 75 wattage.

- Lavatory: two 40 wattage. 


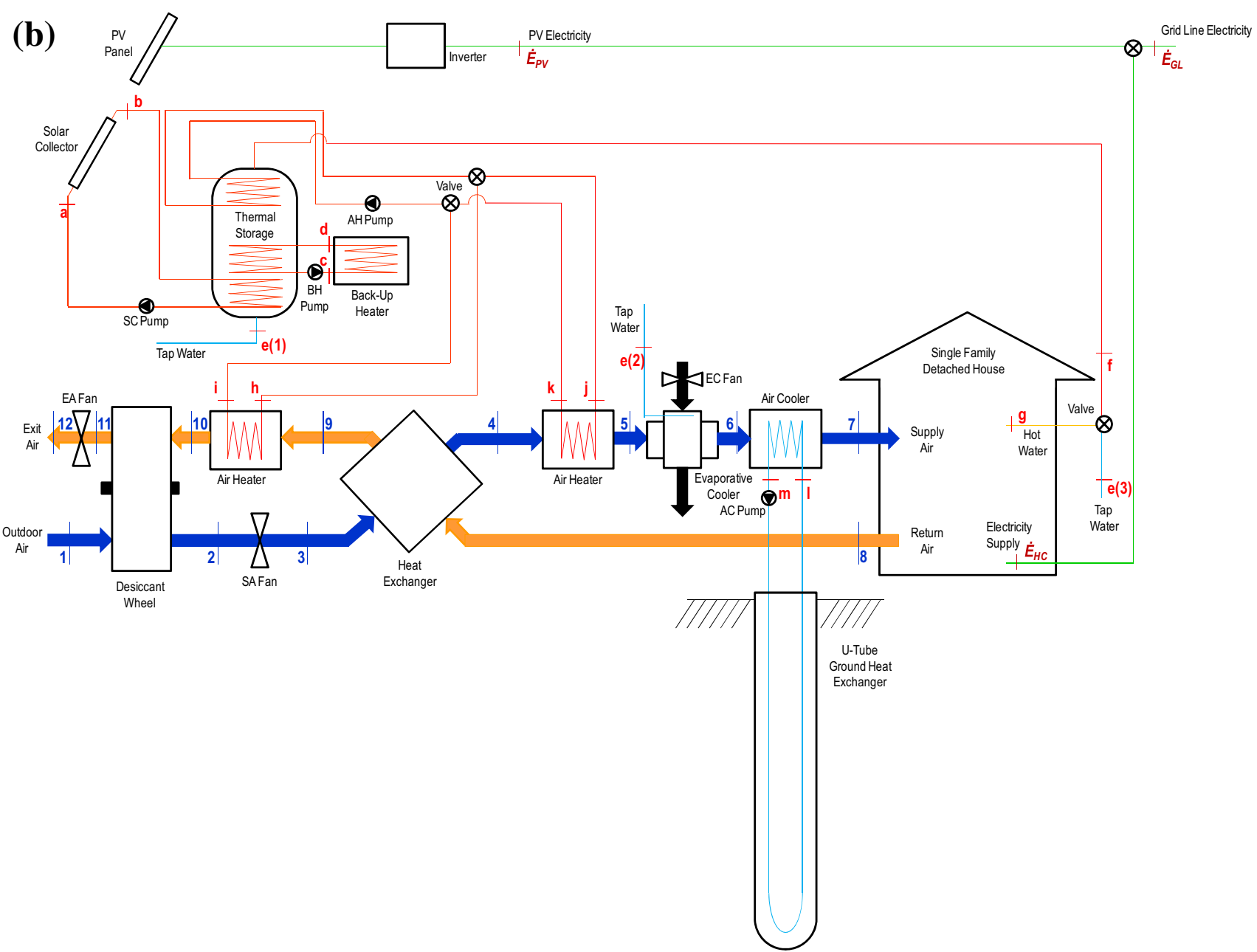

Fig. 2 continued

- Toilet: two 40 wattage.

- Bath tab: five 40 wattage.

- Emergency stair: two 20 wattage.

- Master bedroom: three 75 wattage and two 95 wattage.

During the nighttime, not all of the electrical lighting will operate as expected, therefore, it is estimated that only half of the installed lighting in the second floor (rooms) is required: when the occupants are in the bedrooms, the lightings in the toilet and shower or the hallway are turned off. Figure 5 shows the estimated house appliances usage during weekdays, weekends and holidays. The information for the required appliances is based on the study of Shimoda et al. [26] in their residential end-use simulation model, with some modifications. It includes kitchen appliances, music and video appliances and other appliances for the second floor rooms such as computer and sound system. In the bathroom area, it includes the hair drier.

Figure 6 shows the operational mechanism of a single family detached house for a full year. During summer mode, air dehumidification and cooling is utilized, and during winter mode, air humidification and heating is. Hot water production is always operating for the full year. In the case of lack of available solar energy, the back-up water heater operates. For electric energy, grid line electricity is utilized to augment the electricity generated by the photovoltaic panel. However, in case of more electric energy generation by the photovoltaic panel, the excess energy is fed to the grid line. During the nighttime, full grid line electricity is utilized.

\section{System model}

Figure 7 shows the modeling conducted in transient system simulation representing the schematic diagram presented in Fig. 2. The model utilizes the standard components of TRNSYS [27] and TESS [28]. The design of the system model follows the actual system components, technical specifications and controls to represent the actual installation based on system modeling and simulation [21, 29]. 
Table 1 Technical specification of the single family detached house showing the materials and the thermal properties

\begin{tabular}{|c|c|c|c|c|}
\hline Main parts & Components & Material & Thickness (m) & $U$ value $(\mathrm{W} / \mathrm{m}-\mathrm{K})$ \\
\hline \multirow[t]{8}{*}{ Basement } & \multirow[t]{5}{*}{ Floor } & 3 layers floor & 0.014 & \multirow[t]{5}{*}{0.32} \\
\hline & & Tuplex & 0.003 & \\
\hline & & Concrete & 0.060 & \\
\hline & & EPS & 0.100 & \\
\hline & & Concrete & 0.420 & \\
\hline & Internal wall & Concrete & 0.200 & 3.45 \\
\hline & \multirow[t]{2}{*}{ External wall } & Concrete & 0.220 & \multirow[t]{2}{*}{0.26} \\
\hline & & EPS & 0.100 & \\
\hline \multirow[t]{14}{*}{ First floor } & \multirow[t]{5}{*}{ Floor } & 3 layers floor & 0.015 & \multirow[t]{5}{*}{0.56} \\
\hline & & Tuplex & 0.001 & \\
\hline & & Heat storage concrete & 0.210 & \\
\hline & & EPS & 0.050 & \\
\hline & & Concrete & 0.180 & \\
\hline & \multirow[t]{4}{*}{ Internal wall } & Plaster board & 0.013 & \multirow[t]{4}{*}{1.44} \\
\hline & & Ply wood & 0.009 & \\
\hline & & Ply wood & 0.009 & \\
\hline & & Plaster board & 0.013 & \\
\hline & \multirow[t]{5}{*}{ External wall } & Plaster board & 0.013 & \multirow[t]{5}{*}{0.47} \\
\hline & & Fiber glass & 0.012 & \\
\hline & & Concrete & 0.190 & \\
\hline & & Glass wool & 0.180 & \\
\hline & & Brick & 0.070 & \\
\hline \multirow[t]{16}{*}{ Second floor } & \multirow[t]{5}{*}{ Floor } & 3 layers floor & 0.014 & \multirow[t]{5}{*}{1.02} \\
\hline & & Tuplex & 0.003 & \\
\hline & & Plaster board & 0.030 & \\
\hline & & Ply wood & 0.015 & \\
\hline & & Plaster board & 0.013 & \\
\hline & \multirow[t]{4}{*}{ Internal wall } & Plaster board & 0.013 & \multirow[t]{4}{*}{1.44} \\
\hline & & Ply wood & 0.009 & \\
\hline & & Plywood & 0.009 & \\
\hline & & Plaster board & 0.013 & \\
\hline & \multirow[t]{7}{*}{ External wall } & Plaster board & 0.013 & \multirow[t]{7}{*}{0.47} \\
\hline & & Ply wood & 0.009 & \\
\hline & & Glass wool & 0.184 & \\
\hline & & Plywood & 0.009 & \\
\hline & & Glass wool & 0.155 & \\
\hline & & Glass wool Board & 0.025 & \\
\hline & & Brick & 0.07 & \\
\hline \multirow[t]{11}{*}{ Others } & \multirow[t]{5}{*}{ Roof } & Plaster board & 0.013 & \multirow[t]{5}{*}{0.09} \\
\hline & & Glass wall & 0.419 & \\
\hline & & Vent layer & 0.029 & \\
\hline & & Plywood & 0.012 & \\
\hline & & Tiles & 0.022 & \\
\hline & Entrance door & & & 1.00 \\
\hline & Back door & & & 0.85 \\
\hline & Window (Msora) & & & 0.68 \\
\hline & Window (Velux) & & & 2.03 \\
\hline & Basement window & & & 1.30 \\
\hline & Sliding window & & & 1.10 \\
\hline
\end{tabular}


Fig. 3 Schedule of the single family detached house occupancy: a weekdays (monday to friday), and b weekends (saturday and sunday) and Japanese holidays (a)

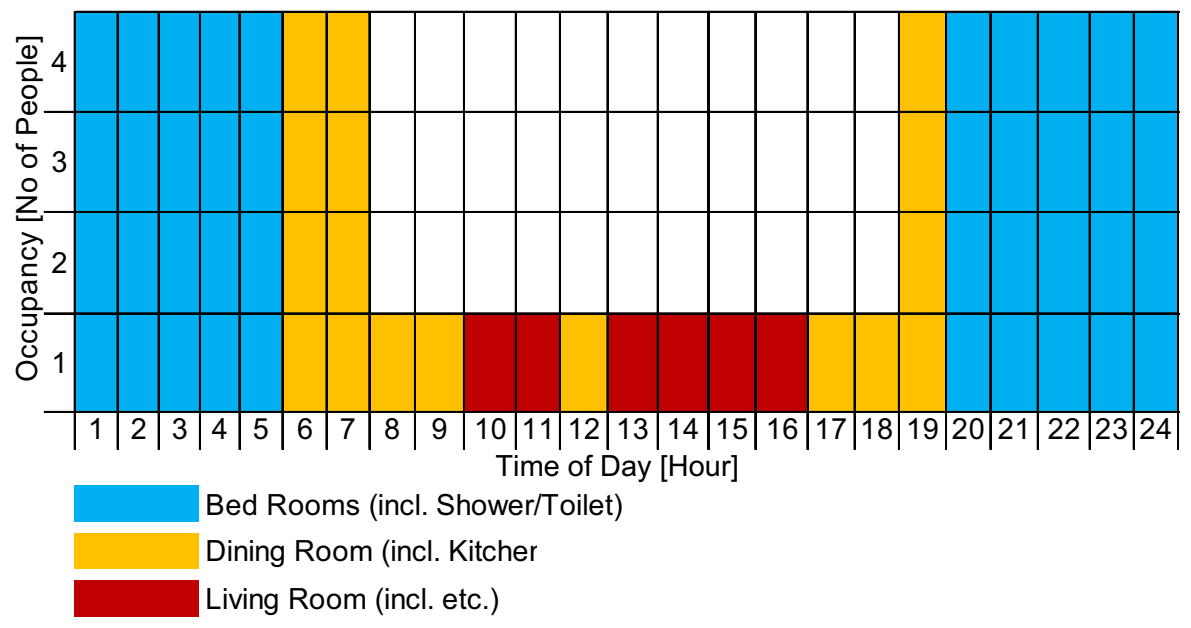

(b)

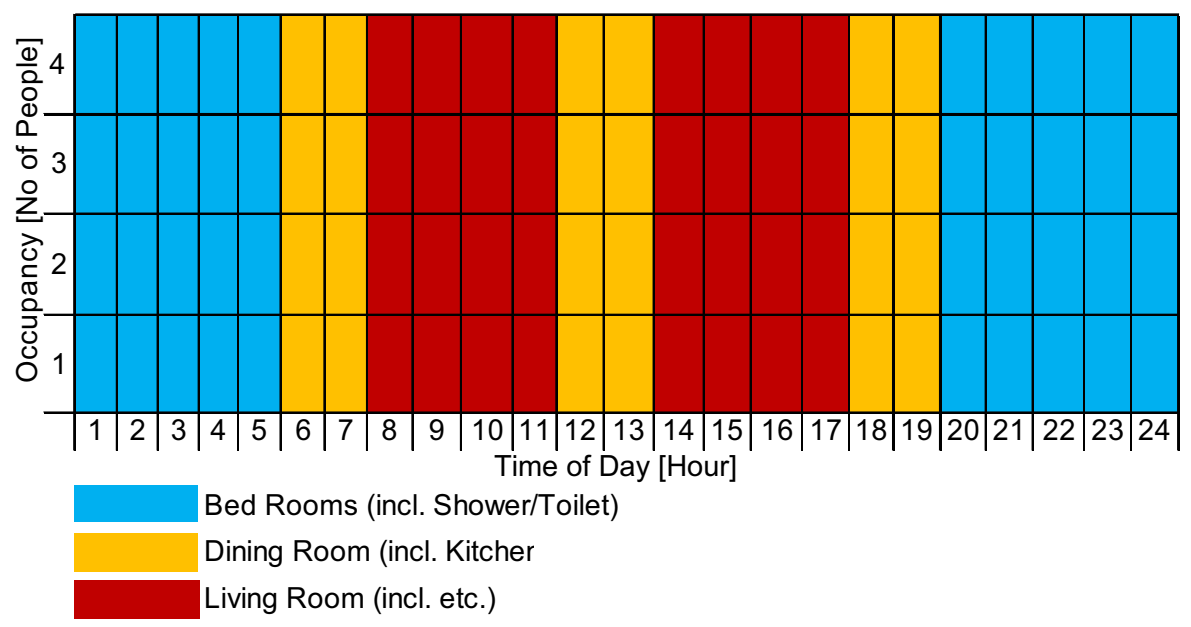

Modeling of the system in TRNYS is very straightforward as long as the system technical information and control function of the model are known. The technical assumptions are based on the known values from the manufacturers, component designs and material specifications. Information is gathered from both available literature and experimental data from previous research.

The system model components and numerical values for parameters shown in Tables 2, 3 and 4 are the following:

- House

- House: Type 56 The house is modeled using the multizone type as it has several interconnected zones (rooms or divisions) shown in Fig. 1. The technical and thermal specifications of the zones are shown in Table 1.

- Thermal system

- Flat Plate Collector: Type la The component models the thermal performance of a variety of collector types using theory. This component is useful when you have technical specifications of the installed flat plate collector as in our case.

- Thermal Storage Tank: Type 60t The thermal performance of a water-filled sensible energy storage tank, subject to thermal stratification, can be modeled by this component. We utilized this type as our tank shown stratification based on our measurement.

- Auxiliary heater: Type 659 Model an external, proportionally controlled fluid heater. External proportional control (an input signal between 0 and 1) is in effect as long as a fluid set point temperature is not exceeded. If the set point is exceeded, the proportional control is internally modified to limit the fluid outlet temperature to the set point.

- Water pump: Type 110 This pump model computes a mass flow rate using a variable control function which is the actual situation of our system. 
Fig. 4 Schedule of daily electric lighting and wattage in the single family detached house: a bed room both weekdays and weekends, b dining room both weekdays and weekends, and c living room both weekdays and weekends
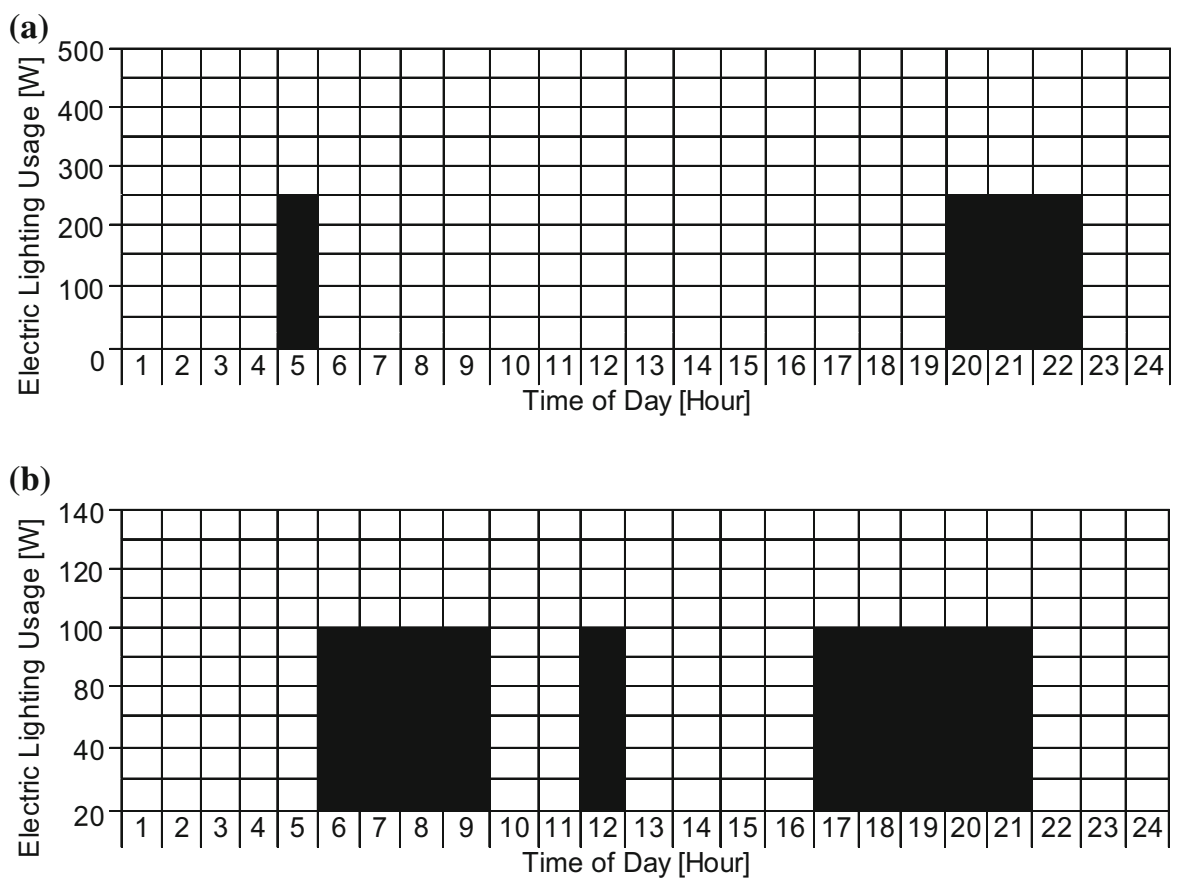

(c)

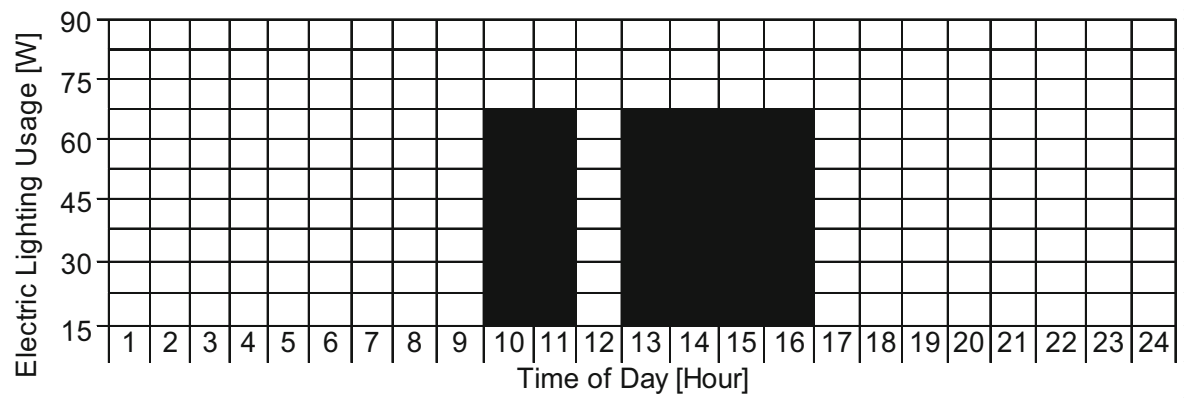

- Water pipe: Type 709 This component models the thermal behavior of fluid flow in a pipe or duct using variable size segments of fluid. It is very important to include water in the model to include the heat losses.

- Heat exchanger: Type 91 A zero capacitance sensible heat exchanger is modeled as a constant effectiveness device that is independent of the system configuration. We used this model as we know the effectiveness of our installed heat exchanger.

- PV system

- Photovoltaic panel: Type 94a A number of simulation options are available for this model. The first of these is the mathematical model used to predict the electrical performance of the array. The "four parameter" model should be used to for single crystal or polycrystalline PVs as in our case.
- Inverter: Type 48a In photovoltaic power systems, two power conditioning devices are needed. The first of these is a regulator, which distributes DC power from the solar cell array to and from a battery (in systems with energy storage) and to the second component, the inverter. The inverter converts the DC power to AC and sends it to the load and/or feeds it back to the utility.

- HVAC system

- Desiccant wheel: Type 151 This is a modified model of the Type 683 component of a rotary desiccant dehumidifier containing nominal silica gel whose performance is based on equations for F1-F2 potentials.

- Sensible wheel: Type 667c Uses a "constant effectiveness-minimum capacitance" approach to model an air to air heat recovery device in which two air streams are passed near each other so that 
Fig. 5 Schedule of daily electric appliances and wattage in the single family detached house: a bed room both weekdays and weekends, b dining room both weekdays and weekends, c living room both weekdays and weekend, and $\mathbf{d}$ extra appliances usage both weekends and holidays

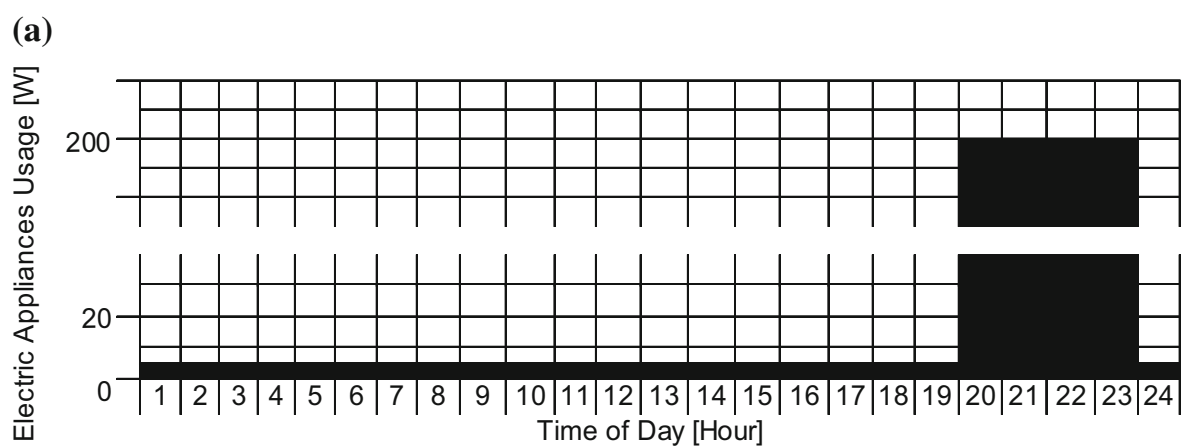

(b)

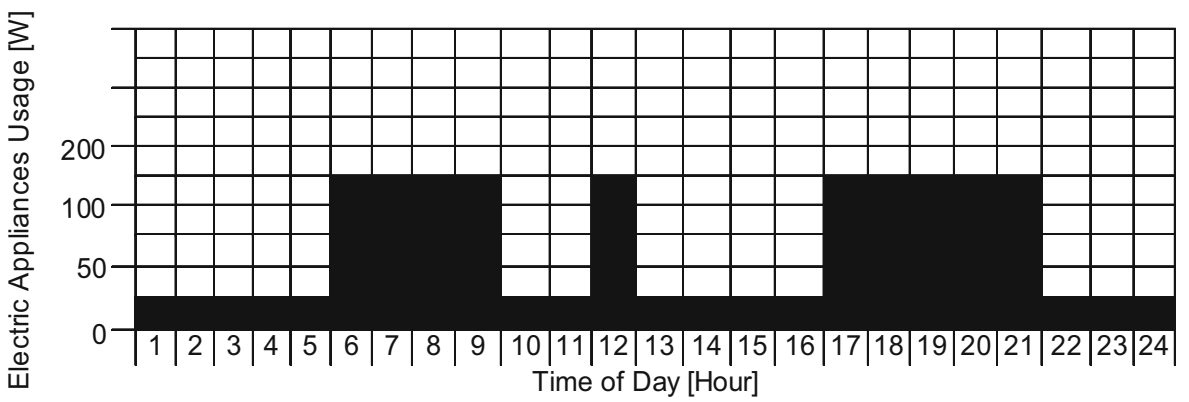

(c)

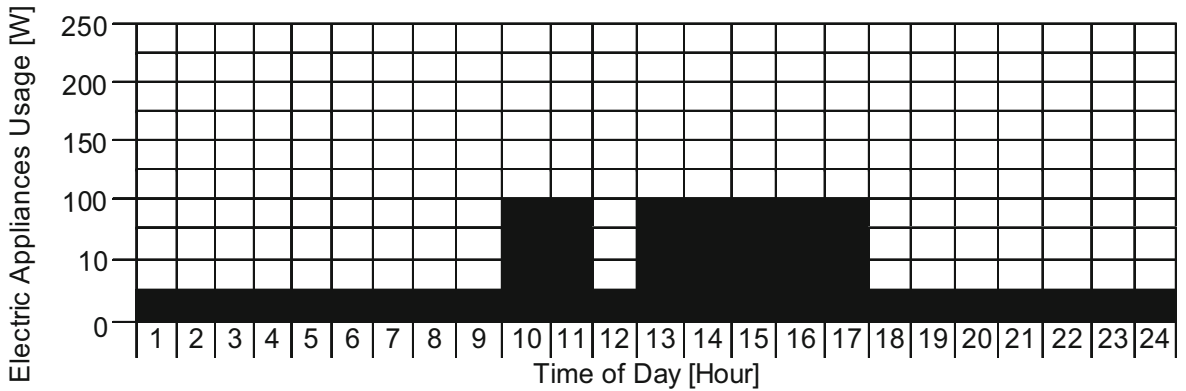

(d)

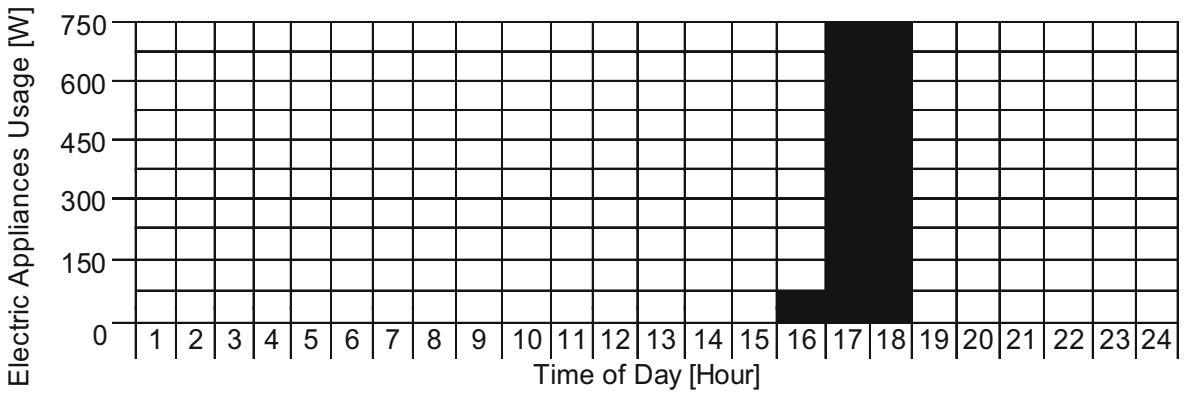

both energy and possibly moisture may be transferred between the streams.

- Air-water heat exchanger: Type 670 Model a heating device in which air is passed across coils containing a hot liquid. The air exits hotter and at the same absolute humidity ratio as it entered the device. The user specifies the air inlet and liquid inlet conditions.
- Evaporative cooler: Type 757a Model an evaporative cooling device for which the user supplies the inlet air conditions of a primary and secondary air stream and the device effectiveness as a function of primary stream inlet air dry bulb temperature and secondary stream inlet air wet bulb temperature.

- Air-to-water heat exchanger: Type 91 A zero capacitance sensible heat exchanger is modeled as 
Fig. 6 Control strategy of the on-site and off-site available renewable energy sources supported model and demonstration single family detached house for the winter and summer modes. Summer mode (set point: $28{ }^{\circ} \mathrm{C}$ ) is set to operate from the beginning of June to end of September and the winter mode (set point: $23{ }^{\circ} \mathrm{C}$ ) from start October to end of May

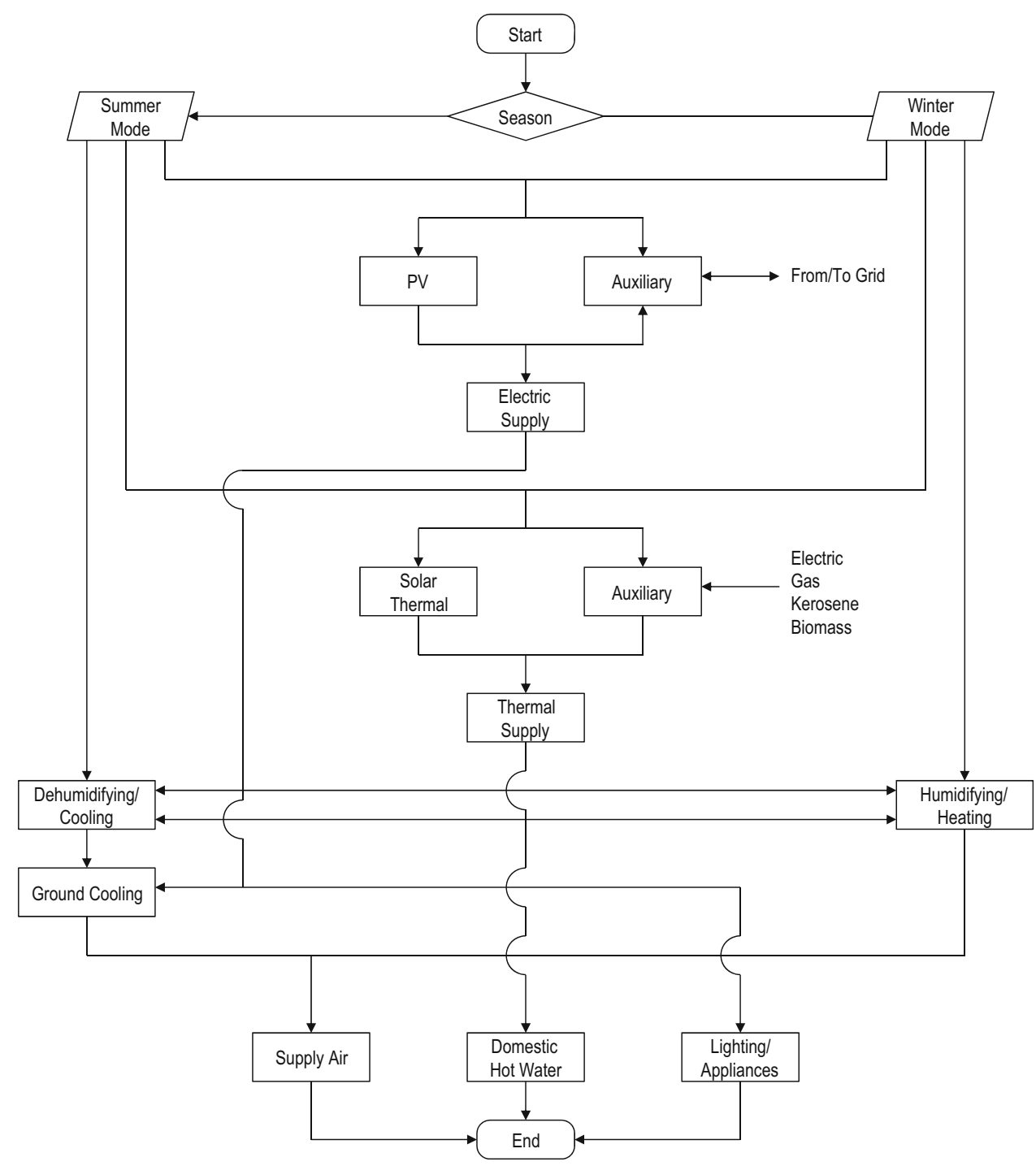

a constant effectiveness device that is independent of the system configuration.

- Borehole heat exchanger: Type 557a This models a vertical heat exchanger that interacts thermally with the ground. This ground heat exchanger model is most commonly used in ground source heat pump applications. In typical U-tube ground heat exchanger applications, a vertical borehole is drilled into the ground. A U-tube heat exchanger is then pushed into the borehole.

Figure 8 shows the estimated domestic hot water consumption profile for daily operation based on data gathered from Zhang et al. [30] for the Japanese household, however, the daily capacity is reduced by half in this study ( $225 \mathrm{l} /$ day) because of energy conservation assumption measures. Hot tub bathing could be done in several available public hot tub baths called Onsen instead of using the house's hot tub. The tap water temperature that refills the tank for domestic hot water supply is assumed to be equal to the temperature one meter below the ground. This assumption is based on the fact that the water pipe supplying the house is buried at this depth. Figure 9 shows the profile of the ambient air, ground surface and below the ground for depths of $0.5,1,5,10,15,20,25$ and $30 \mathrm{~m}$. As shown in the numerical profile data, below $10 \mathrm{~m}$ underground, the temperature is stable year round.

The implementation of the daylighting effect in the model and simulation is based on the assumption that all the lighting in the first floor is compact fluorescent lamp with equivalent lumen of $23 \mathrm{~W}=1580$ lumen (lighting). When the equivalent daylight is equal to half of the total lumen equivalent of the electrical lighting for the dining room (6743 lumen), the electrical lighting is turned off, the same as in the case for the daylight model and simulation 


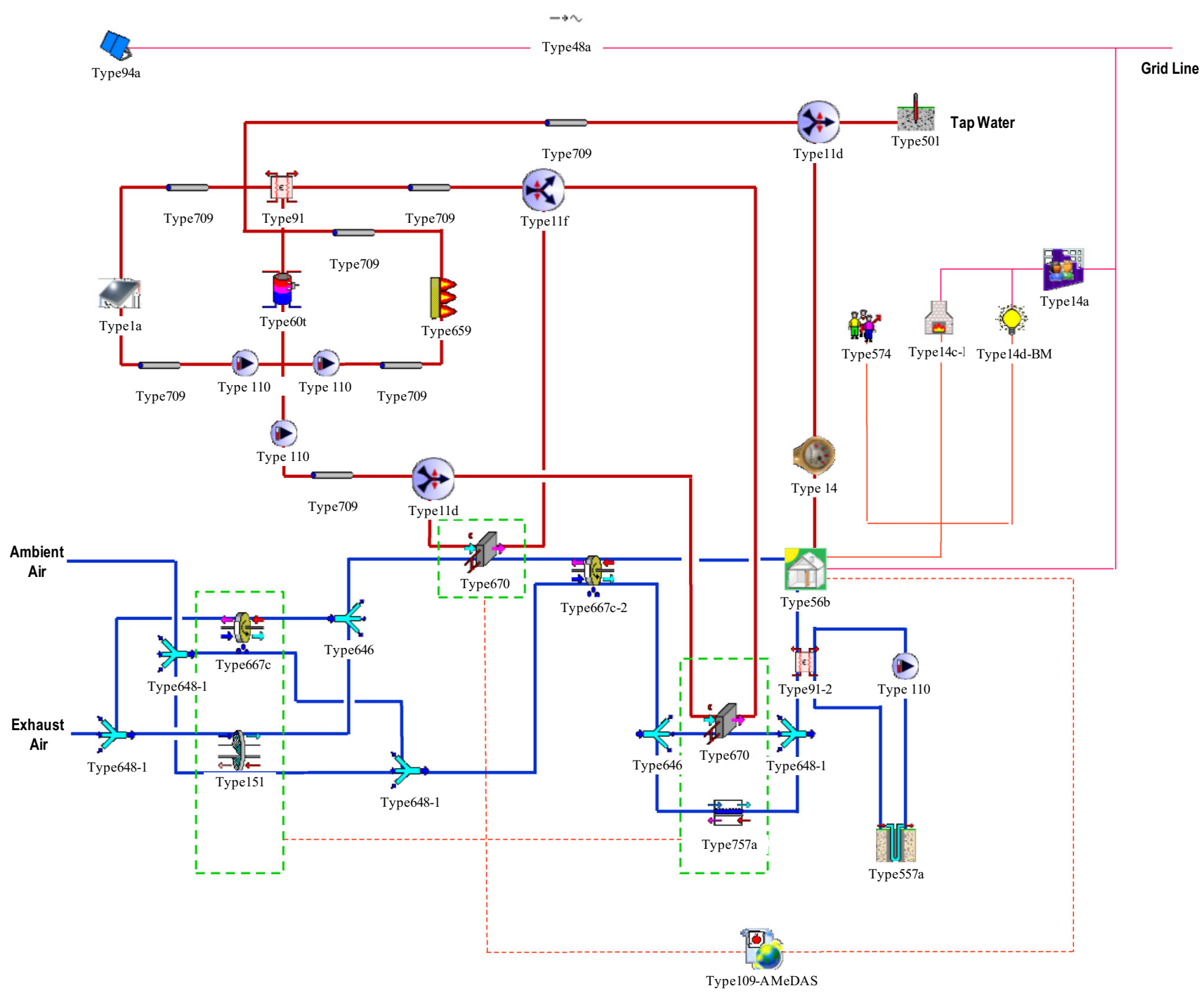

Fig. 7 Model diagram of the alternative energy and technologies supported single family detached house in the transient system simulation (TRNSYS) program. It shows the different components in TRNSYS used in the model development

for the living room (4330 lumen). The second floor is not considered for daylighting as its lighting operates only during nighttime.

\section{House and system evaluation}

The developed model of the solar energy supported single family detached house was numerically operated using the supplied information from the house shown in Table 1 and the profile of its operation shown in Figs. 3, 4, 5 and 6, based on information gathered from the house. In addition, the climatic condition was used for solar radiation, ambient temperature, humidity and wind speed. The ground temperature shown in Fig. 9 was used to select the appropriate depth of the ground heat exchanger at ten meters, and the estimated tap water temperature is based on the underground water pipe being buried one meter deep.
To evaluate the potential of different back-up thermal energy sources, natural gas, kerosene and biomass heaters are investigated. These energy sources are already used in Japanese housing except for the biomass which is not yet in mass application.

- Natural gas water heater: the required amount of natural gas is based on the $25 \mathrm{~m}^{3}$ which equals to $1054 \mathrm{MJ}$ with lower heating value (LHV) of $45 \mathrm{MJ} / \mathrm{kg}$. The cost of the natural gas is based on the price of US\$2.34/ $\mathrm{m}^{3}$ [31]. The natural gas is based on the $0.20 \mathrm{~kg}-\mathrm{CO}_{2} / \mathrm{kWh}\left(\mathrm{CO}_{2}\right)$ [32].

- Kerosene gas water heater: the required kerosene is based on the lower heating value (LHV) of $43.1 \mathrm{MJ} / \mathrm{kg}$ (kerosene). The density of kerosene is based on the density of $0.81715 \mathrm{~kg} / \mathrm{l}$. The price of kerosene is US\$22.76/18 1 [33]. The kerosene emission is $0.26 \mathrm{~kg}$ $\mathrm{CO}_{2} / \mathrm{kWh}\left(\mathrm{CO}_{2}\right)[32]$. 
Table 2 Components and parametric values of thermal system: the parametric values are based on the actual system installation and available technical specification

\begin{tabular}{|c|c|c|c|}
\hline Component & Parameter & Value & Unit \\
\hline \multirow[t]{7}{*}{ Flat plate collector (Type 1): } & Collector area & 12 & $\mathrm{~m}^{2}$ \\
\hline & Collector inclination & 45 & $\circ$ \\
\hline & $\begin{array}{l}\text { Fluid specific heat } \\
\text { ( } 25 \% \text { propylene glycol) }\end{array}$ & 4 & $\mathrm{~kJ} / \mathrm{kg}-\mathrm{K}$ \\
\hline & Tested flow rate & 120 & $\mathrm{~kg} / \mathrm{m}^{2}-\mathrm{h}$ \\
\hline & Intercept efficiency & 0.594 & \\
\hline & Efficiency slope & 16.2 & $\mathrm{~kJ} / \mathrm{h}-\mathrm{m}^{2}-\mathrm{K}$ \\
\hline & Efficiency curvature & 0 & \\
\hline \multirow[t]{19}{*}{ Thermal storage tank (Type 60): } & Tank volume & 0.37 & $\mathrm{~m}^{3}$ \\
\hline & Tank height & 1.4 & $\mathrm{~m}$ \\
\hline & Tank perimeter & 1.82 & $\mathrm{~m}$ \\
\hline & Height of water inlet & Tank bottom & \\
\hline & Height of water outlet & Tank top & \\
\hline & Tank loss coefficient & 0.92 & $\mathrm{~W} / \mathrm{m}^{2}-\mathrm{K}$ \\
\hline & $\begin{array}{l}\text { Fluid thermal conductivity } \\
\text { (Water) }\end{array}$ & 0.6 & $\mathrm{~W} / \mathrm{m}-\mathrm{K}$ \\
\hline & $\begin{array}{l}\text { Height of first HX inlet } \\
\text { (From bottom) }\end{array}$ & 0.5 & $\mathrm{~m}$ \\
\hline & Height of first HX outlet & Tank top & \\
\hline & $\begin{array}{l}\text { Height of second HX inlet } \\
\text { (Below tank top) }\end{array}$ & 0.5 & $\mathrm{~m}$ \\
\hline & Height of second HX outlet & Tank top & \\
\hline & $\begin{array}{l}\text { Height of third HX inlet } \\
\text { (Above tank middle) }\end{array}$ & 0.5 & $\mathrm{~m}$ \\
\hline & HX tube inlet diameter & 0.01 & $\mathrm{~m}$ \\
\hline & HX tube outlet diameter & 0.012 & $\mathrm{~m}$ \\
\hline & HX fin diameter & 0.022 & $\mathrm{~m}$ \\
\hline & HX surface area & 1 & $\mathrm{~m}^{2}$ \\
\hline & HX tube length & 20 & $\mathrm{~m}$ \\
\hline & HX wall thermal conductivity & 401 & $\mathrm{~W} / \mathrm{m}-\mathrm{K}$ \\
\hline & HX material conductivity & 401 & $\mathrm{~W} / \mathrm{m}-\mathrm{K}$ \\
\hline \multirow[t]{5}{*}{ Water pump (Type 110) } & Power coefficient & 1 & $\mathrm{~kJ} / \mathrm{h}$ \\
\hline & Number of power coefficient & 1 & \\
\hline & Motor heat loss fraction & 0 & \\
\hline & Total pump efficiency & 0.6 & \\
\hline & Motor efficiency & 0.9 & \\
\hline \multirow[t]{9}{*}{ Water pipe (Type 709) } & Inside diameter & 0.02 & $\mathrm{~m}$ \\
\hline & Outside diameter & 0.025 & $\mathrm{~m}$ \\
\hline & $\begin{array}{l}\text { Pipe length } \\
\text { (Collector loop, desiccant loop) }\end{array}$ & 20 & $\mathrm{~m}$ \\
\hline & $\begin{array}{l}\text { Pipe length } \\
\text { (Auxiliary loop) }\end{array}$ & 5 & $\mathrm{~m}$ \\
\hline & Pipe thermal conductivity & 0.24 & $\mathrm{~W} / \mathrm{m}-\mathrm{K}$ \\
\hline & Fluid thermal conductivity & 4 & $\mathrm{~kJ} / \mathrm{h}-\mathrm{m}-\mathrm{K}$ \\
\hline & Insulation thickness & 0.04 & $\mathrm{~m}$ \\
\hline & Insulation thermal conductivity & 0.043 & $\mathrm{~W} / \mathrm{m}-\mathrm{K}$ \\
\hline & Outer surface convective coefficient & 3 & $\mathrm{~kJ} / \mathrm{h}-\mathrm{m}^{2}-\mathrm{K}$ \\
\hline \multirow[t]{3}{*}{ Back-up water heater (Type 659) } & Rated capacity & 5 & $\mathrm{~kW}$ \\
\hline & Set point temperature & 65 & ${ }^{\circ} \mathrm{C}$ \\
\hline & Boiler efficiency & 0.8 & \\
\hline
\end{tabular}


Table 3 Components and parametric values of the desiccant-based heating, ventilating and air-conditioning system: the parametric values are based on the actual system installation and available technical specification

\begin{tabular}{llll}
\hline Component & Parameter & Value \\
\hline Air heating coil (Type 670) & Effectiveness & 0.8 \\
Desiccant wheel (Type 151) & F1 effectiveness & 0.235 & 0.8 \\
& F2 effectiveness & 0.8 & \\
Enthalpy wheel (Type 667): & Sensible effectiveness & 0.7 & 0.85 \\
Heat exchanger (Type 760): & Latent effectiveness & 15 & \\
Ground heat exchanger (Type 557a) & Sensible effectiveness & Borehole deep & 0.01664 \\
& Outer radius of U-tube pipe & 0.01372 & $\mathrm{~m}$ \\
& Inner radius of U-tube pipe & $\mathrm{m}$ \\
Evaporative cooler (Type 757) & Pipe thermal conductivity & 4.19 & $\mathrm{~m}$ \\
\hline
\end{tabular}

- Biomass water heater: the mass requirement for biomass (wood pellets) is based on the lower heating value (LHV) of $3100 \mathrm{kWh} / \mathrm{m}^{3}$. The wood pellets density is $650 \mathrm{~kg} / \mathrm{m}^{3}$. The price of wood pellets is based on the US\$0.90/kg [34]. The biomass is considered negligible of $\mathrm{CO}_{2}$ emission as it is considered bioenergy in this study [35]. Bioenergy means that the amount of $\mathrm{CO}_{2}$ emitted during biomass combustion is enough to grow the biomass sources.

In electricity pricing, the household price of electricity consumption is based on the flat rate of US\$0.30/kWh [36]). In Japan, the price for feed-in tariff for photovoltaic generated electric energy is US $\$ 0.54 / \mathrm{kWh}$ [1]. The carbon dioxide emission for the supplied grid line electricity is based on the information after the Fukushima nuclear accident. The emission per $\mathrm{kWh}$ is $0.583 \mathrm{~kg}-\mathrm{CO}_{2} / \mathrm{kWh}$ for FY 2012 [37]. All fuel cost and expense calculations are based on the year 2014. The conversion of the Japanese Yen to the US dollar is approximately US\$ $1 \approx ¥ 90$ as of 2014 .

\section{Analytical formulation}

The total thermal energy supplied to the system is

$\dot{Q}_{\mathrm{TE}}=\dot{Q}_{\mathrm{SE}}+\dot{Q}_{\mathrm{Aux}}$

The collected solar thermal energy is

$\dot{Q}_{\mathrm{SE}}=\dot{m}_{\mathrm{SC}} C_{P_{\mathrm{W}}}\left(T_{b}-T_{a}\right)$

The available solar energy in the collector is

$\dot{E}_{\mathrm{SE}}=A_{\mathrm{SC}} I_{R}=\dot{Q}_{\mathrm{SE}} / \eta_{\mathrm{SC}}$

The thermal energy provided by auxiliary heater is

$\dot{Q}_{\mathrm{Aux}}=\dot{m}_{\mathrm{Aux}} C_{P_{\mathrm{W}}}\left(T_{d}-T_{c}\right)$
The available power supplied to auxiliary heater is

$\dot{E}_{\text {Aux }}=\dot{m}_{\mathrm{F}}(\mathrm{LHV})=\dot{E}_{\mathrm{E}}=\dot{Q}_{\text {Aux }} / \eta_{\text {Aux }}$

The power cost supplied to auxiliary heater is

$\dot{C}_{\mathrm{Aux}}=\dot{m}_{\mathrm{F}} c_{\mathrm{Aux}}$

The carbon dioxide emission by auxiliary heater is

$\dot{P}_{\text {Aux }}=\dot{E}_{\text {Aux }} p_{\text {Aux }}$

The total consumption of thermal power is presented as

$\dot{Q}_{\mathrm{TE}}=\dot{Q}_{\mathrm{HW}}+\dot{Q}_{\mathrm{HC}}$

The thermal power for hot water production is

$\dot{Q}_{\mathrm{HW}}=\dot{m}_{\mathrm{HW}} C_{P_{\mathrm{W}}}\left(T_{f}-T_{e(1)}\right)$

The thermal power for heating coil during summer season is

$\dot{Q}_{\mathrm{HC}}=\dot{m}_{\mathrm{HC}} C_{P_{\mathrm{W}}}\left(T_{h}-T_{i}\right)$

The thermal power for heating coil during winter season is

$\dot{Q}_{\mathrm{HC}}=\dot{m}_{\mathrm{HC}} C_{P_{\mathrm{W}}}\left(T_{j}-T_{k}\right)$

The generated electricity from the photovoltaic is the product of the direct current (DC) generated by the photovoltaic panel and the inverter efficiency shown as

$\dot{E}_{\mathrm{PV}}=\dot{E}_{\mathrm{PP}} \eta_{\mathrm{I}}$

Since the installed photovoltaic roof tile panels are connected to gridline, there are two scenarios in which the electricity flows. The first scenario shows that when the photovoltaic electricity is not enough to support the house electricity consumption, the gridline electricity supports 
Table 4 Components and parametric values of the electric system: the parametric values are based on the actual system installation and available technical specification

\begin{tabular}{|c|c|c|c|}
\hline Component & Parameter & Value & Unit \\
\hline \multicolumn{4}{|c|}{ Photovoltaic (PV) panel (Type 94a) } \\
\hline \multirow[t]{10}{*}{ PV panel Type No. 1} & Module size & $1535 \times 280$ & $\mathrm{~mm}$ \\
\hline & Number of module in series & 83 & \\
\hline & Number of modules in parallel & 1 & \\
\hline & Number of cells wires in series & 12 & \\
\hline & $\begin{array}{l}\text { Module short circuit current } \\
\text { (Reference conditions) }\end{array}$ & 5.4 & A \\
\hline & $\begin{array}{l}\text { Module open circuit voltage } \\
\text { (Reference conditions) }\end{array}$ & 13.3 & $\mathrm{~V}$ \\
\hline & Reference temperature & 298 & $\mathrm{~K}$ \\
\hline & Reference isolation & 1000 & $\mathrm{~W} / \mathrm{m}^{2}$ \\
\hline & $\begin{array}{l}\text { Module voltage at maximum power point } \\
\text { (Reference conditions) }\end{array}$ & 10.5 & $\mathrm{~V}$ \\
\hline & $\begin{array}{l}\text { Module current at maximum power point } \\
\text { (Reference conditions) }\end{array}$ & 4.9 & A \\
\hline \multirow[t]{10}{*}{ PV panel Type No. 2} & Module size & $1228 \times 280$ & $\mathrm{~mm}$ \\
\hline & Number of module in series & 27 & \\
\hline & Number of modules in parallel & 1 & \\
\hline & Number of cells wires in series & 12 & \\
\hline & $\begin{array}{l}\text { Module short circuit current } \\
\text { (Reference conditions) }\end{array}$ & 5.4 & A \\
\hline & $\begin{array}{l}\text { Module open circuit voltage } \\
\text { (Reference conditions) }\end{array}$ & 9.7 & V \\
\hline & Reference temperature & 298 & $\mathrm{~K}$ \\
\hline & Reference isolation & 1000 & $\mathrm{~W} / \mathrm{m}^{2}$ \\
\hline & $\begin{array}{l}\text { Module voltage at maximum power point } \\
\text { (Reference conditions) }\end{array}$ & 7.6 & $\mathrm{~V}$ \\
\hline & $\begin{array}{l}\text { Module current at maximum power point } \\
\text { (Reference conditions) }\end{array}$ & 4.9 & A \\
\hline \multicolumn{4}{|l|}{ Inverter (Type 48q) } \\
\hline & Efficiency & 0.88 & \\
\hline
\end{tabular}

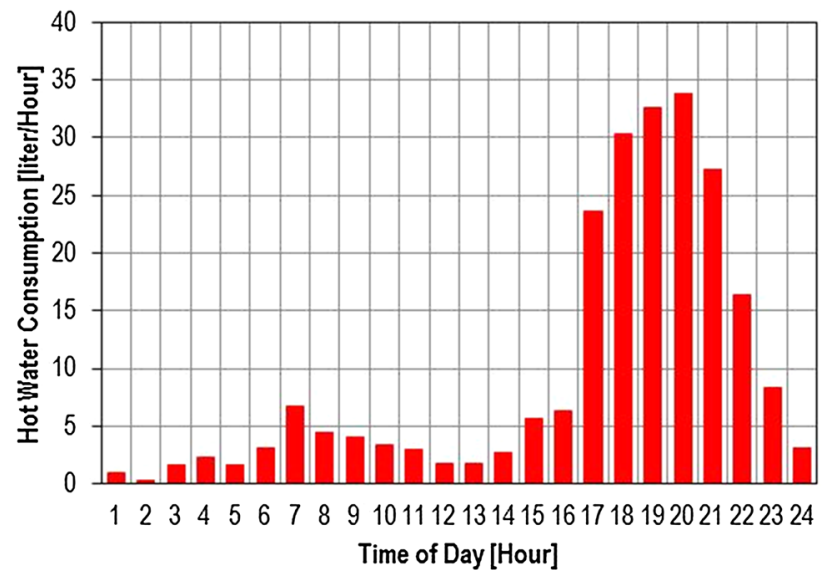

Fig. 8 Domestic hot water consumption profile used in this numerical investigation. This patter is based from previous study with the consumption of $225 \mathrm{l} / \mathrm{h}$ in this paper
$\dot{E}_{\mathrm{PV}}+\dot{E}_{\mathrm{GL}}=\dot{E}_{\mathrm{EC}} \quad\left(\right.$ if $\left.\dot{E}_{\mathrm{PV}}<\dot{E}_{\mathrm{EE}}\right)$

In the second scenario, when the electricity consumption is less than of the electricity generated by the photovoltaic roof tiles, the excess electricity is transferred to the gridline through feed-in tariff mechanism.

$\dot{E}_{\mathrm{PV}}=\dot{E}_{\mathrm{EC}}+\dot{E}_{\mathrm{GL}} \quad\left(\right.$ if $\left.\dot{E}_{\mathrm{PV}}>\dot{E}_{\mathrm{HC}}\right)$

The house electricity consumption is distributed to the electric appliances, lighting and the HVAC system shows as

$\dot{E}_{\mathrm{EC}}=\dot{E}_{\mathrm{App}}+\dot{E}_{\text {Lights }}+\dot{E}_{\mathrm{HVAC}}$

The cooling load for the single family detached house during summer season is

$\dot{Q}_{\mathrm{CL}}=\dot{m}_{\mathrm{SA}}\left(h_{7}-h_{8}\right)$ 


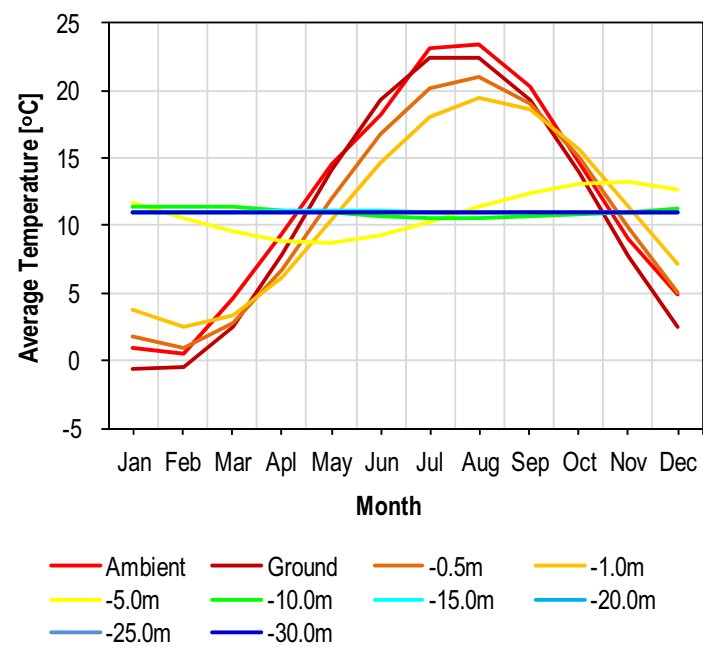

Fig. 9 Monthly average profile for outdoor air, ground surface and ground temperatures from 0.5 to $30 \mathrm{~m}$ below the ground surface

The heating load for the single family detached house during winter season is

$\dot{Q}_{\mathrm{HL}}=\dot{m}_{\mathrm{SA}}\left(h_{8}-h_{7}\right)$

The total conditioning load for the single family detached for one full year is

$Q_{\text {Total }}=\int_{\text {Summer }} \dot{Q}_{\mathrm{CL}} \mathrm{d} t+\int_{\text {Winter }} \dot{Q}_{\mathrm{HL}} \mathrm{d} t$

The contribution of solar energy for thermal energy requirement of the house is presented as the solar thermal fraction (STF). The expression is based on full year (365 days), however, it could be used for any span of time.

$\mathrm{STF}=\int_{d}^{365} \dot{Q}_{\mathrm{TE}} \mathrm{d} t /\left(\int_{d}^{365} \dot{Q}_{\mathrm{SE}} \mathrm{d} t+\int_{d}^{365} \dot{Q}_{\mathrm{Aux}} \mathrm{d} t\right)$

The contribution of solar energy for the electric energy requirement of the house is presented as the solar electric fraction (SEF). The expression is based on full year (365 days) and can be used for any span of time.

$\mathrm{SEF}=\int_{d}^{365} \dot{E}_{\mathrm{EC}} \mathrm{d} t /\left(\int_{d}^{365} \dot{E}_{\mathrm{HC}} \mathrm{d} t \pm \int_{d}^{365} \dot{E}_{\mathrm{GL}} \mathrm{d} t\right)$

The \pm means that when it is negative, the photovoltaic roof tiles is generating more than of the house electricity consumption and it is distributed in the grid line. In the case of positive sign, the generated electricity from the installed photovoltaic roof tiles is not enough to support the house electricity consumption and gridline electricity is needed.


Fig. 10 Monthly average outdoor air conditions based on the AMeDAS weather data (architectural Institute of Japan) for the city of Sendai where the data is used for the simulation in single family detached house: a outdoor air (OA) dry bulb temperature; and b outdoor air (OA) humidity ratio

\section{Results and discussion}

\section{Air conditions}

Figure 10 shows the monthly average outdoor air conditions-temperature and humidity ratio, for 1 year using the Japan Meteorological Agency-AMeDAS (Automated Meteorological Data Acquisition System) data for the city of Sendai (Northeastern, Japan) with coordinates of $38.2667^{\circ} \mathrm{N}, 140.8667^{\circ} \mathrm{E}$ [38]. It shows that the average temperature before July and after August is below $20^{\circ} \mathrm{C}$. The average temperature shows that August is the hottest month. The outdoor air temperature reaches over $35{ }^{\circ} \mathrm{C}$ during the months of July and September. In terms of humidity ratio, the humidity ratio before July and after 


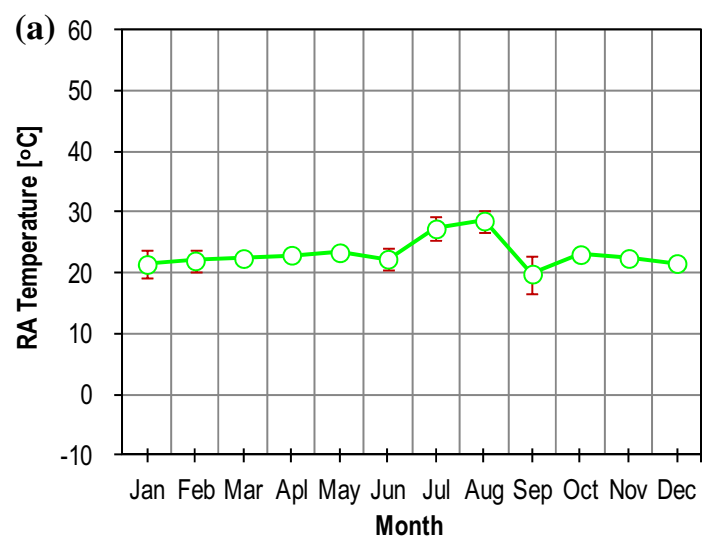

$-\circ-$ Ave

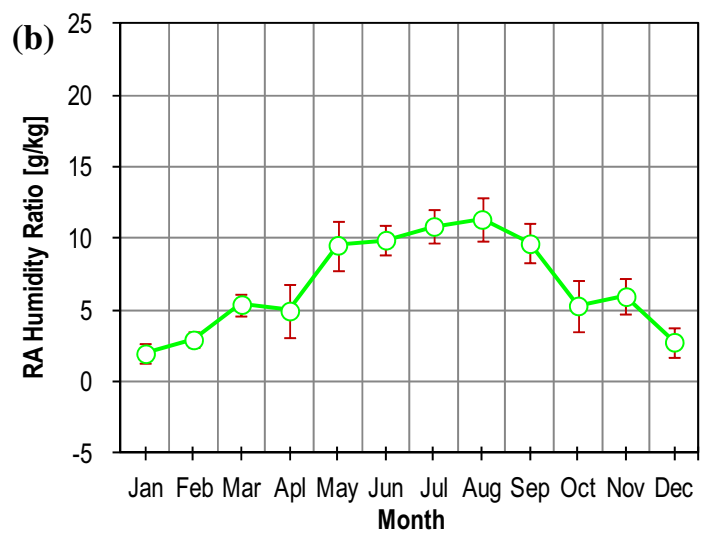

$-\circ-$ Ave

Fig. 11 Monthly average house air conditions when using the solardesiccant heating, ventilating and air-conditioning system for the installed system: a return air (RA) dry bulb temperature; and b return air (RA) humidity ratio

August is below $15 \mathrm{~g} / \mathrm{kg}$. The month with the highest humidity ratio is August, reaching above $20 \mathrm{~g} / \mathrm{kg}$ (maximum).

Figure 11 shows the monthly average house return air temperature and humidity ratio going back to the solardesiccant heating, ventilating and air-conditioning system. The return air temperature shows that during winter mode, the return air temperature is maintained at above $20^{\circ} \mathrm{C}$ and during summer time below $30^{\circ} \mathrm{C}$. The highest and lowest temperature values are due to the sudden change of the supply air temperature due to the operation of the solardesiccant heating, ventilation and air-conditioning system during the sudden change of the air temperature. However, this happens only rarely. In fact, the fluctuation/deviation of the house temperature is very small. The house return air humidity ratio shows that during winter time, the house humidity ratio is maintained above 2 and $10 \mathrm{~g} / \mathrm{kg}$. During the summer time, the house return air humidity ratio is maintained above $10 \mathrm{~g} / \mathrm{kg}$ and below $12 \mathrm{~g} / \mathrm{kg}$ (average).
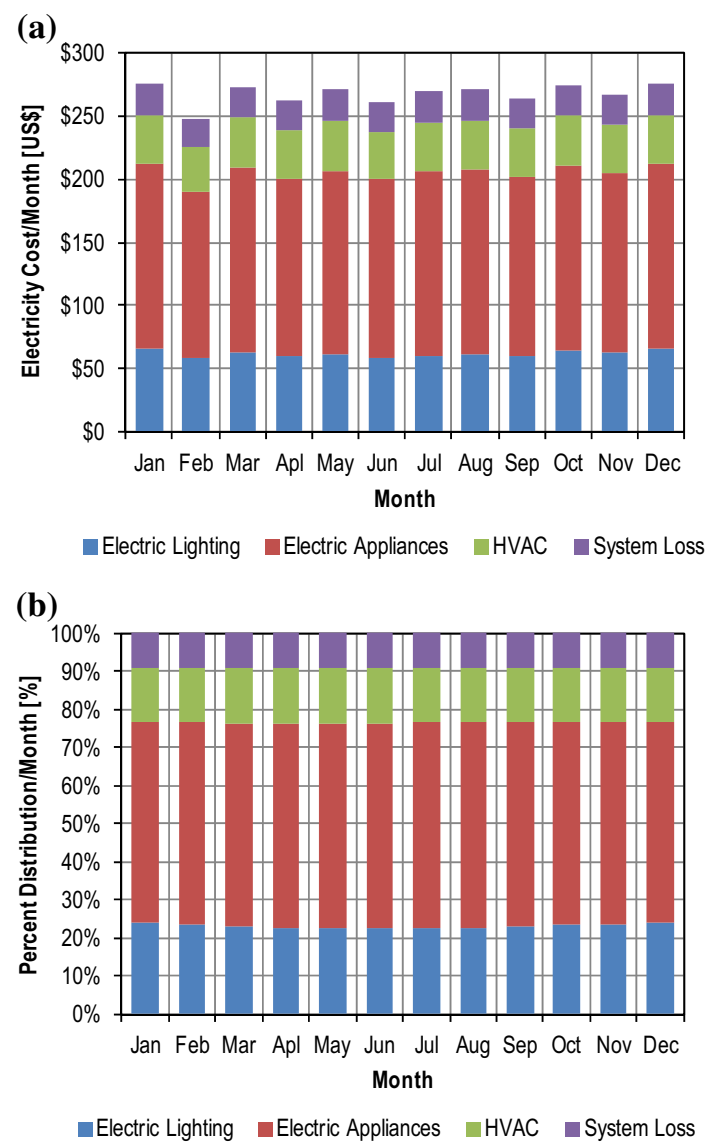

Fig. 12 Monthly electricity cost for lighting, appliances, HVAC and system losses based on grid electricity (assuming the house has no photovoltaic panels): a electricity cost; and $\mathbf{b}$ cost distribution

\section{Electricity cost and $\mathrm{CO}_{2}$ emission}

Figure 12 shows the monthly electricity cost, of which the average is almost US\$282 per month when the house depends on all electricity coming from the grid line at the price of $\$ 0.30 / \mathrm{kWh}$. This consumption is based on the $10 \%$ system losses of the electrical system in the house. The Japanese house is expected to have losses between 10 and $17 \%$ [39]. As this model and demonstration house use new technologies, a $10 \%$ loss is assumed. The electrical losses are considered as an additional thermal load to the house HVAC system. During the winter season, it becomes an additional heat source and during summer season, it becomes an additional heat load. It shows that the electric lighting accounted for almost US\$64 of the monthly house bill. The electrical appliances accounted to around US\$128 per month. The HVAC system consumes around US\$39 per month. The system losses amounted to almost US\$26 per month. As presented, the daylighting effect is not too effective in the single family detached house in electricity saving due to the high electric consumption during the nighttime. The studies of Wong et al. [40] show the same 
(a)

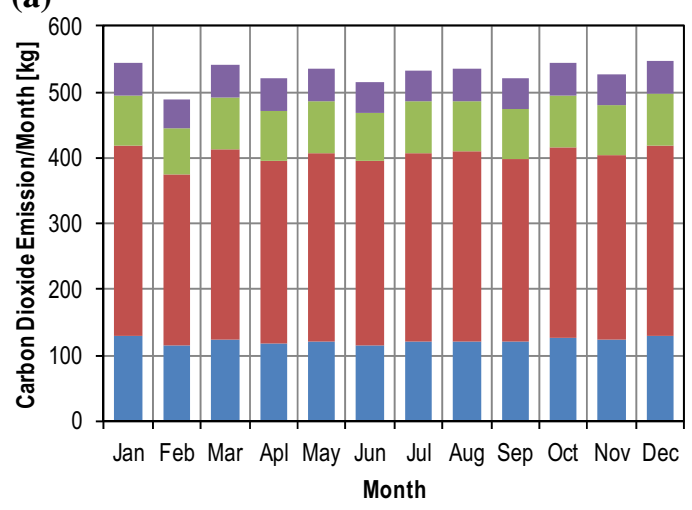

Electric Lighting Electric Appliances $\quad$ HVAC $\square$ System Loss

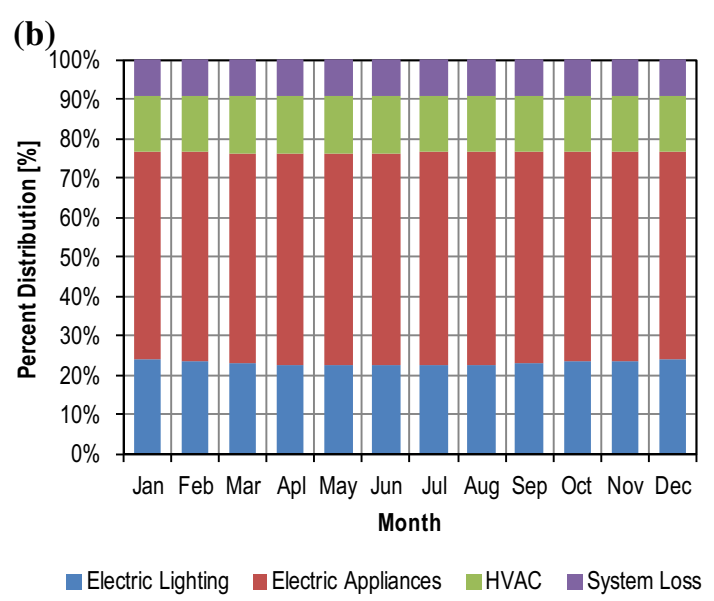

Fig. 13 Monthly carbon dioxide emission based on electricity consumption for lighting, appliances, HVAC and system losses based on grid electricity (assuming the house has no photovoltaic panels): a carbon dioxide emission; and $\mathbf{b}$ emission distribution

observation of the daylighting for households. Furthermore, it shows that $60 \%$ of the house's monthly electricity consumption is for electrical appliances.

Figure 13 shows the monthly equivalent of carbon dioxide emission based on the electricity consumption from the grid line. As presented, the usage of electrical appliances contributes almost $350 \mathrm{~kg}$ per month of $\mathrm{CO}_{2}$ emission. Electrical lighting contributes around $100 \mathrm{~kg}$ per month of $\mathrm{CO}_{2}$ emission. The usage of HVAC contributes almost $90 \mathrm{~kg}$ per month of $\mathrm{CO}_{2}$ emission. The system losses contribute almost $30 \mathrm{~kg}$ per month. This means that around $60 \%$ of the $\mathrm{CO}_{2}$ emission is due to the electrical appliances usage with $20 \%$ for the electrical lighting. In order to reduce the electrical usage or consumption, these two factors should be given attention such as use of more efficient appliances. In addition, a high efficient lighting system could be used such as the light emitting diode (LED). (a)
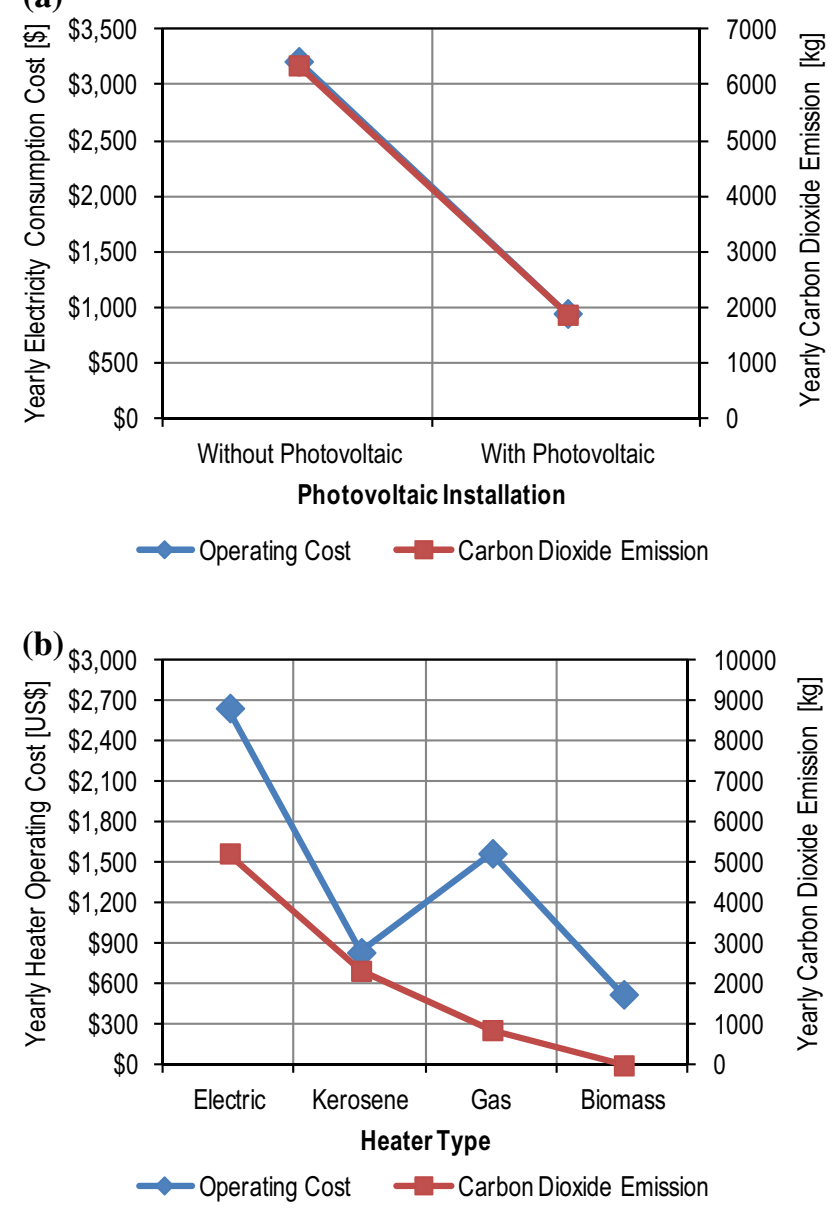

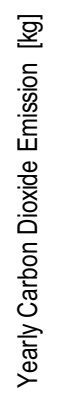

Fig. 14 Yearly operational cost and carbon dioxide emission of the single family detached house for electricity consumption and water heater operation: a electricity consumption without and with photovoltaic and $\mathbf{b}$ different water heater operation

Figure 14a shows the yearly electricity consumption and carbon dioxide emission when the house relies completely on grid line electricity to support the lighting, appliances, HVAC system together with system losses, compared to when some of the electricity consumption is supported by the installed photovoltaic roof tiles. The results show that the electricity cost is reduced from US\$3205 per year to US\$962 per year with a saving of almost $70 \%$. Based on the reduction of grid line electricity consumption, the yearly carbon dioxide emission is reduced from 5500 to $1600 \mathrm{~kg}$ per year showing a reduction of around $71 \%$. This reduction contributed to both the economic benefit to the owner as well as to the environment.

Figure $14 \mathrm{~b}$ shows the yearly comparative cost and carbon dioxide emission when different water heaters are used. From the US $\$ 2564$ yearly cost of operating the water heater using electricity, it goes down to US\$769 yearly for the kerosene water heater, US $\$ 1282$ per year for the gas water heater and US\$513 for biomass water heater. On the 
other hand, there is a reduction of carbon dioxide emission from $4500 \mathrm{~kg}$ yearly for the electric water heater to 2400 per year for the kerosene water heater, 1000 for the gas water heater and completely zero for biomass water heater when biomass is considered a biofuel which is a renewable energy source. With this economic and environmental benefit of using an alternative water heater, it is very important to know which of the fuels are readily available for use in different houses, as fuel availability is also very important in water heater selection.

\section{PV installation}

The horizontal and PV roof tiles inclination annual irradiance in Sendai is 1222 and $1301 \mathrm{kWh} / \mathrm{m}^{2}$. With the present installed photovoltaic roof tiles on the south facing roof of the house with the capacity of $5.32 \mathrm{~kW}_{\mathrm{p}}$, surface area of $45.7 \mathrm{~m}^{2}$, inclination angle of $50.2^{\circ}$, it has an expected annual generation of $6607 \mathrm{kWh}$. The installed PV roof tiles have a final yield of $1242 \mathrm{kWh} / \mathrm{kW}_{\mathrm{p}}$. The study of Liu et al. [41] shows a yield of $1297 \mathrm{kWh} /$ $\mathrm{kW}_{\mathrm{P}}$ when the $\mathrm{PV}$ inclination angle is optimized to $28.8^{\circ}$ for Sendai. Figure 15a shows the comparison between the electricity consumption per month when using all grid line electricity and when using electricity generated from the installed photovoltaic roof tiles. It shows a huge difference in the cost of electricity, accounting for a saving possibly amounting to almost $75 \%$ yearly. From almost US\$282 per month of electricity billing, it is down to around US $\$ 90$ per month. In addition, as presented in Fig. $15 \mathrm{~b}$, the carbon dioxide emissions are reduced as much as $75 \%$ yearly. From almost $470 \mathrm{~kg}$ per month of $\mathrm{CO}_{2}$ emission, it goes down to around $150 \mathrm{~kg}$ per month. Hence, photovoltaic roof tiles provide economic benefits to the house owner in the form of a huge saving in electricity bills, and they also contribute to the reduction of carbon dioxide emissions to the atmosphere, thus reducing the carbon footprint of the house.

\section{Water heater fuels}

Figure 16a compares the cost of operating different water heaters for the required heating. It shows that electric water heater is the most costly of all the heaters. When operating a gas water heater, the saving will be $50 \%$ per year. When a kerosene water heater is used, the saving goes to $70 \%$ per month. When a biomass water heater is used, the saving goes to $80 \%$ per month. Clearly, this means that when using alternative energy sources for the water heater, economic benefits and savings result. However, operation of biomass-fueled water heater is more complicated than the other water heaters. This problem could be easily solved using automatic feeding mechanism for biomass-

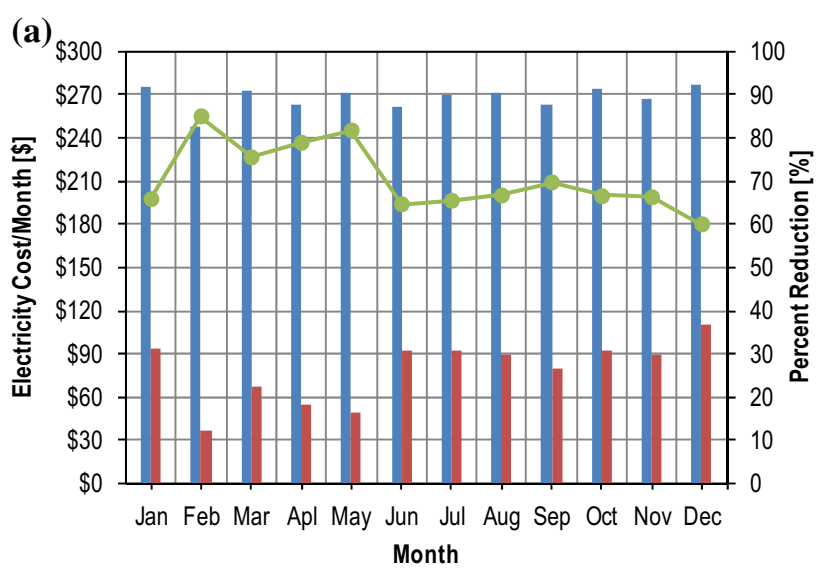

Without Photovoltaic With Photovoltaic $\quad-$-Reduction

(b)

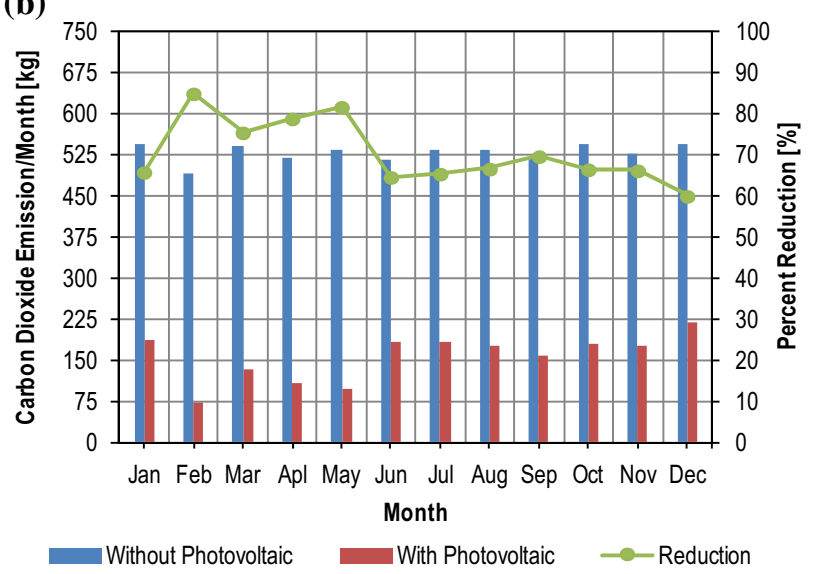

Fig. 15 Monthly electricity cost and carbon dioxide emission with and without photovoltaic supplied electricity for lighting, appliances, HVAC and system losses based on grid electricity: a electricity cost; and $\mathbf{b}$ carbon Dioxide emission

fueled water heater. Figure 16b shows the environmental benefit of using an alternative water heater other than the electric water heater. When the house water heater is changed to gas, the carbon dioxide emission per month is reduced to $55 \%$. When the electric water heater is changed to kerosene, the carbon dioxide emission is reduced to $48 \%$. However, when a biomass water heater is used, the reduction of carbon dioxide emission is $100 \%$ with the assumption that the biomass fuel is a biofuel. Therefore, the type of heater used in the house will contribute not only to the economic benefit of the owner but to the environment as well.

\section{Case analysis}

Figure 17 shows the case studies shown in Table 5 to further investigate the modification of the currently installed system in the detached house (Case 1). Case 2 is when increasing the size of the flat plate collector by $4 \mathrm{~m}^{2}$, 

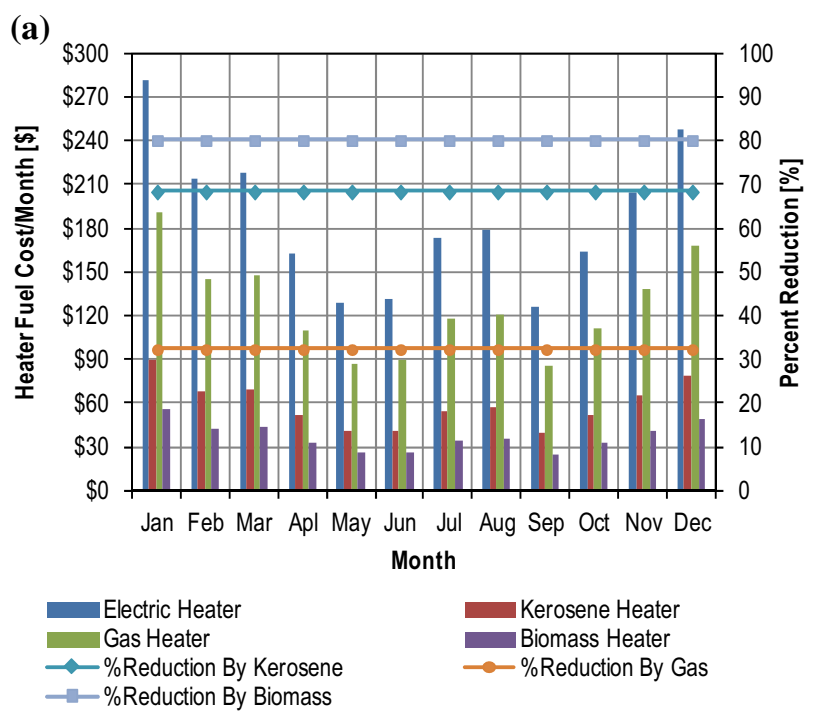

(b)

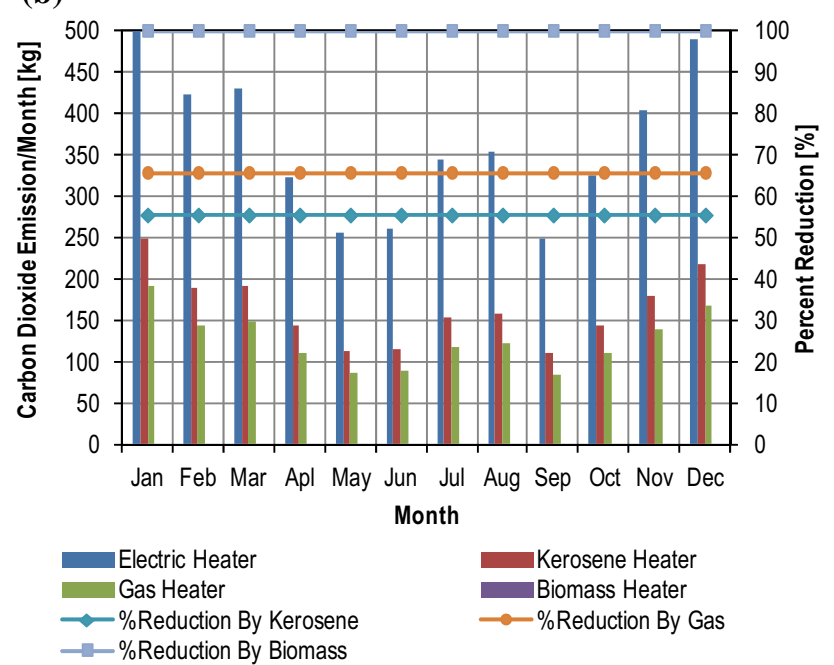

Fig. 16 Monthly cost and carbon dioxide emission for auxiliary heater operation: a cost; and, $\mathbf{b}$ carbon dioxide emission

double the size of the thermal storage tank and covered whole the south facing roof with PV panels. Case 3 is when increasing the size of the flat plate collector to cover the available space for solar thermal collector, triple the size of the thermal storage tank and cover the entire south facing roof with PV panels. Case 4 is when flat plate collector is the maximum size possible shown in Case 3, the thermal storage is double same to Case 2 and PV panels are the maximum size possible. Case 5 is when the size of flat plate collector is the maximum presented above; the size of thermal storage tank is double of case 2 and with maximum possible size of PV panels. Case 6 is when Case 4 is added with borehole heat exchanger to support the cooling requirement of the house during full summer. Based on the results for the different cases, it shows that the present case (Case 1) can be further improved to make the detached

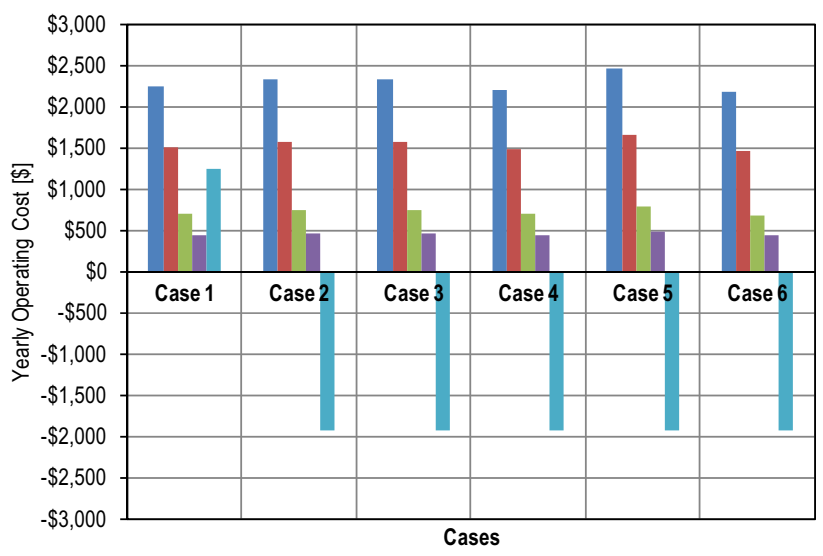

Electric Heater $\square$ Gas Heater $\square$ Kerosene Heater $\square$ Biomass Heater $\square$ Electricity

Fig. 17 Yearly operational cost and benefits for different cases of the single family detached house with different specifications of solar thermal collector, photovoltaic panels and water heater types

house generate more electricity that could be sold to the grid line through the fid-in tariff law of Japan. As presented, doubling the surface area of the installed photovoltaic roof tiles can produce a yearly excess of electricity thus making the house a net energy producer. It shows that it can earn money from the grid line amounting to almost US $\$ 1923$ per year. Also, the case studies show that when using an alternative water heater, the house can save a lot of money by using a biomass heater.

Figure 18 shows the carbon dioxide emissions per year for the different cases mentioned in Table 5. In the case of the present system, Case 1, the consumption of electricity for appliances, lighting, HVAC and system losses generates carbon dioxide emissions. However, when using a larger area of photovoltaic roof tiles covering the south facing roof (optimizing the size of the roof), the system generates a surplus of electricity resulting in further reduction of carbon dioxide emission expressed as a carbon minus to the grid line. The application of a different water heater, particularly a biomass heater also makes the house a carbon minus. Therefore, by installing of photovoltaic roof tiles with a capacity greater than the house uses makes the house an energy generating home (EGH) and a negative carbon emission home (NCEH), by the application of a biomass heater. It means that optimizing the capability of the house to utilize different alternative energy sources coupled with new building technologies make the house an energy generating home (EGH) and a negative carbon emission home (NCEH).

\section{Conclusions}

Numerical performance evaluation of the solar energy and alternative energy supported single family detached house with desiccant-based air-conditioning system was 
Table 5 System cases for the installed thermal system, electric system and desiccantbased heating, ventilating and air-conditioning system to the alternative energy and technologies supported single family detached house

\begin{tabular}{lllllll}
\hline & Case $1^{\mathrm{a}}$ & Case 2 & Case 3 & Case 4 & Case 5 & Case 6 \\
\hline $\begin{array}{l}\text { Flat plate collector } \\
\text { Area }\left(\mathrm{m}^{2}\right)\end{array}$ & 12 & 16 & 20 & 20 & 20 & 20 \\
$\begin{array}{l}\text { Thermal storage tank } \\
\text { Volume }\left(\mathrm{m}^{3}\right)\end{array}$ & 0.37 & 0.74 & 1.1 & 0.74 & 1.48 & 0.74 \\
$\begin{array}{l}\text { Photovoltaic panel } \\
\text { Panel 1 }\left(\mathrm{m}^{2}\right)\end{array}$ & 36.1 & 72.2 & 72.2 & 72.2 & 72.2 & 72.2 \\
$\begin{array}{l}\text { Panel 2 }\left(\mathrm{m}^{2}\right) \\
\text { Geothermal heat exchanger }\end{array}$ & 9.6 & 19.3 & 19.3 & 19.3 & 19.3 & 19.3 \\
\multicolumn{1}{l}{ Installation } & No & No & No & No & No & Yes \\
\hline
\end{tabular}

${ }^{a}$ Base case

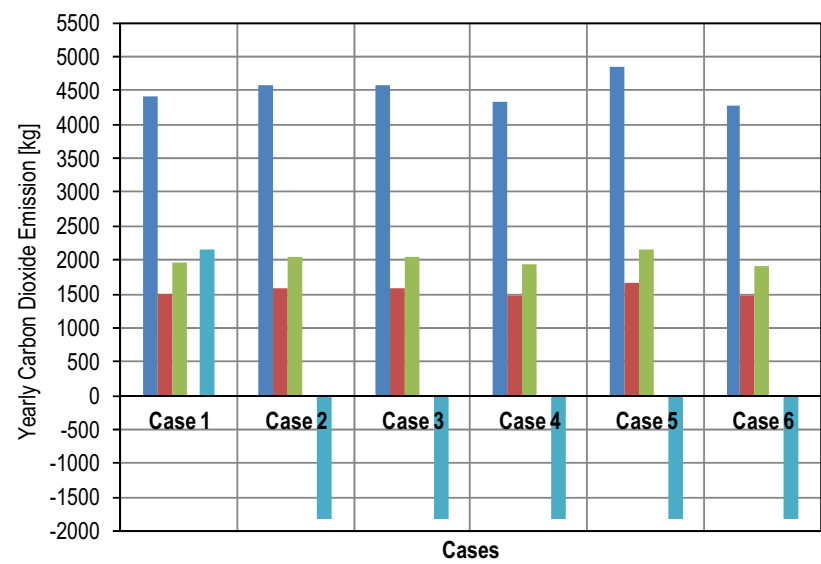

EElectric Heater $\square$ Gas Heater $\square$ Kerosene Heater $\square$ Biomass Heater $\square$ Electricity

Fig. 18 Yearly carbon dioxide emission reduction and benefit for different cases of the single family detached house with different specifications of solar thermal collector, photovoltaic panels and water heater types

conducted in a transient system simulation program to evaluate the economic and environmental benefits of utilizing different sources of energy aside from the solar thermal and photovoltaic electricity generated by the house.

Based on the numerical evaluation of the solar energy supported single family detached house:

- The alternative energy and technology supported house consumed $52 \mathrm{GJ} / \mathrm{year}$ based on the energy for the air heating, desiccant regeneration, domestic hot water, electric lighting, electric appliances and auxiliary electricity for the HVAC system. The gathered information of the houses in the region is almost $65 \mathrm{GJ} /$ year [42]. Please be aware that this model house is larger than the typical houses in the region by around 15-20\%. Even with this, the house still has lower energy consumption.
- The energy consumption per floor area of the house is $371 \mathrm{kWh} / \mathrm{m}^{2}$-year without considering the floor areas for the toilets, showers and stock rooms. The lower consumption of the house of $22.22 \%$ difference with respect to the houses in the region [42] is due to good insulation, air tightness, energy efficient lighting and a new desiccant-based HVAC system. Even with $22.22 \%$ difference, the house mentioned in this paper is still more economical and environmental friendly during the operation as most of the energy consumed came from the energy supported by solar energy and biomass.

- The installation of the photovoltaic roof tiles has a great impact on electricity cost saving resulting in a $75 \%$ saving from grid line electricity consumption. In addition, it contributes to the reduction of the carbon dioxide emission of the house due to the minimization of grid line electricity consumption.

- An alternative water heater provides both economic and environmental benefits to the house by reducing the house heater consumption cost by almost $80 \%$. Also, it makes the water heating operation zero carbon dioxide emission when a biomass source is considered as biofuel.

- Case studies show that increasing the size of the installed photovoltaic roof tiles or maximizing the available roof area (almost the same to the size of the south facing roof) makes the house an energy generating home (EGH), as well as a negative carbon emission home (NCEH). This is possible when the water heater is supported by biomass fuel.

- Using desiccant dehumidification with evaporative cooling of supply air is not enough to support the cooling in peak summer days due to its limited capacity in air dehumidification for further indirect evaporative cooling. The application of borehole heat exchanger to cool the dehumidified supply air can provide the house cooling requirement during the peak summer season. 
The paper shows that utilization of alternative energy sources both on-site and off-site, particularly renewable energy sources such as solar energy and biomass energy. The house becomes an electric energy generator that can feed into the grid line and can contribute to lower the peak load during summer season. The utilization and application of renewable energy sources is very important if the different houses could get the initial cost in the installation of the said devices through bank loans or government programs as these are very expensive for ordinary family houses.

In addition, utilization of biomass fuel eliminates the carbon dioxide emission for water heating, as biofuel is a carbon neutral fuel. In different countries, there are excess biomass products that can be turned to pellets to be utilized as alternative fuels in water heating. Although, biomass heater is more expensive but with government support, the capital cost could be gradually paid by the house owners. It shows that desiccant-based air-conditioning system supported the thermal environmental condition of the house both with economic and environmental benefits when coupled with different renewable energy sources compared when using the typical air-conditioning system such as the vapor compression system which is totally electric-powered system.

At present, the economic and environmental calculation are based on the operation only due to the difficulty in getting the correct values of the system cost and environmental impact as the system is to be optimized upon field testing and evaluation. Once the actual system is optimized, the numerical analysis will be done both considering the economic and environmental benefits. The actual system will serve as the benchmark for further numerical evaluation and case analysis.

The concepts and results of the study is important for other countries seeking to utilize different available sources of energy for the house operation using different technologies. For example, utilization of different alternative energy sources both off-site and on-site could reduce the house's dependency on grid line electricity and fossil fuel. The utilization of a biomass fuel water heater could reduce the carbon dioxide emission in lieu of electric water heater.

\section{Compliance with ethical standards}

Conflict of interest No potential conflict of interests declared by the authors.

Open Access This article is distributed under the terms of the Creative Commons Attribution 4.0 International License (http://crea tivecommons.org/licenses/by/4.0/), which permits unrestricted use, distribution, and reproduction in any medium, provided you give appropriate credit to the original author(s) and the source, provide a link to the Creative Commons license, and indicate if changes were made.

\section{References}

1. FIT: Feed-in tariff scheme in Japan. http://www.meti.go.jp/eng lish/policy/energy_environment/renewable/pdf/summary201207. pdf. Accessed Oct 2014

2. Zero-Nuclear Policy: Zero-nuclear policy ready for inclusion in new energy and environment strategy. http://mainichi.jp/english/ english/newsselect/news/20120912p2a00m0na014000c.html. Accessed Aug 2014

3. Enteria, N., Yoshino, Y., Mochida, A., Takaki, R., Yoshie, R., Mitamura, T., Baba, S.: Synergization of clean energy utilization, clean technology development and controlled clean environment through thermally activated desiccant cooling system. In: Proceedings of 2nd International Conference in Energy Sustainability, 10-14 Aug 2008, Jacksonville, Florida, USA, vol. 1, pp. 303-313

4. Komiyama, R., Marnay, C.: Japan's residential energy demand outlook to 2030 considering energy efficiency standards "toprunner approach". In: Proceedings of 2008 ACEEE Summer Study on Energy Efficiency in Buildings, Scaling Up: Building Tomorrow's Solutions, 17-22 Aug 2008, Pacific Grove, California, USA

5. Japan Energy: Japan's energy situation-Trends in policies and technologies. http://www.tillvaxtanalys.se/tua/export/sv/filer/pub likationer/working-paper-pm/WP_PM_2010_06.pdf. Accessed Sept 2014

6. German Village: German Village produces $321 \%$ more energy than it needs! http://inhabitat.com/german-village-produces-321more-energy-than-it-needs/. Accessed Aug 2014

7. Solar Decathlon: US Department of Energy, USA. http://www. solardecathlon.gov/. Accessed Sept 2014

8. LCCM (Life Cycle Carbon Minus): Houses as advanced energyefficient housing for a low-carbon society. http://www.kenken.go. jp/english/contents/lccm/index.html. Accessed Sept 2014

9. Yang, L., Lam, J., Tsang, C.L.: Energy performances of building envelopes in different climate zones in China. Appl. Energy 85, 800-817 (2008)

10. Zhou, J., Chen, Y.: A review on applying ventilated double-skin façade to buildings in hot-summer and cold-winter zone in China. Renew. Sustain. Energy Rev. 14, 1321-1328 (2010)

11. Abdallah, A.S.H., Yoshino, H., Goto, T., Enteria, N., Radwan, M.M., Eid, M.A.: Parametric investigation of solar chimney with new cooling tower integrated in a single room for New Assiut city, Egypt climate. Int. J. Energy Environ. Eng. 5(92), 1-9 (2014). doi:10.1007/s40095-014-0092-6

12. Abdallah, A.S.H., Yoshino, H., Goto, T., Enteria, N., Radwan, M.M., Eid, M.A.: Integration of evaporative cooling technique with solar chimney to improve indoor thermal environment in the New Assiut City, Egypt. Int. J. Energy Environ. Eng. 4(45), 1-15 (2013). doi:10.1186/2251-6832-4-45

13. Balachandra, P., Shekar, G.L.: Energy technology portfolio analysis: an example of lighting for residential sector. Energy Convers. Manag. 42, 813-832 (2001)

14. Murray, A.G., Mills, B.F.: Read the label! Energy star appliance label awareness and uptake among US consumers. Energy Econ. 33, 1103-1110 (2011)

15. Ashina, S., Nakata, T.: Energy-efficiency strategy for $\mathrm{CO}_{2}$ emissions in a residential sector in Japan. Appl. Energy 85, 101-114 (2008)

16. Santos, I.P., Ruther, R.: The potential of building-integrated (BIPV) and building-applied photovolatics (BAPV) in singlefamily, urban residences at low latitudes in Brazil. Energy Build. 50, 290-297 (2012)

17. Takuma, Y., Inoue, H., Nagano, F., Ozaki, A., Takaguchi, H., Watanabe, T.: Detailed research for energy consumption of 
residences in Northern Kyushu, Japan. Energy Build. 38, 1349-1355 (2006)

18. Syed, A.M., Fung, A.S.: Analysis of PV/wind potential in the Canadian residential sector through high-resolution building energy simulation. Int. J. Energy Res. 33, 342-357 (2009)

19. Marszal, A.J., Heiselberg, P., Bourrelle, J.S., Musall, E., Voss, K., Sartori, I., Napolitano, A.: Zero energy building-a review of definitions and calculation methodologies. Energy Build. 43, 971-979 (2011)

20. Renewable Energy. Feed-in tariff scheme for renewable energy. http://www.meti.go.jp/english/policy/energy_environment/renew able/pdf/summary201209.pdf. Accessed Aug 2015

21. Enteria, N., Yoshino, H., Takaki, R., Mochida, A., Satake, A., Baba, S., Ishihara, H., Yoshie, R.: Case analysis of utilizing alternative energy sources and technologies for the single family detached house. Sol. Energy 105, 243-263 (2014)

22. Enteria, N., Awbi, H., Yoshino, H.: Application of renewable energy sources and new building technologies for the Philippine single family detached house. Int. J. Energy Environ. Eng. 6(3), 267-294 (2015). doi:10.1007/s40095-015-0174-0

23. Zero Energy House: A zero energy house-a low energy house with PV system in Kanagawa, Japan. IEA-SHC Task 28/ECBCS Annex 38: Sustainable Solar Cooling. International Energy Agency. http://www.iea.shc.org. http://www.ecbcs.org. Accessed Sept 2014

24. Hamada, Y., Nakamura, M.: Field performance of a Japanese low energy home relying on renewable energy. Energy Build. 33, 805-814 (2001)

25. Yamaguchi, Y., Fujimoto, T., Shimoda, Y.: Occupancy behavior model for households to estimate high-temporal resolution residential electricity demand profile. In: Proceedings of 12 th Conference of International Building Performance Simulation Association, 14-16 Nov 2011, Sydney, Australia

26. Shimoda, Y., Fujii, T., Morikawa, T., Mizuno, M.: Development of residential energy end-use simulation model at city scale. In: Proceedings of 8th International Building Performance Simulation Association, 11-14 Aug 2003, Eindhoven, Netherlands

27. TRNSYS: TRNSYS 16.1. Transient system simulation program. University of Wisconsin at Madison. http://www.trnsys.com/. Accessed Sept 2014

28. TESS: TESS, Thermal Energy System Specialists. http://www. tess-inc.com/trnsys. Accessed Sept 2014

29. Enteria, N., Yoshino, H., Mochida, A., Satake, A., Yoshie, R., Takaki, R., Yonekura, H., Mitamura, T., Tanaka, Y.: Performance of solar-desiccant cooling system with silica-gel $\left(\mathrm{SiO}_{2}\right)$ and titanium dioxide $\left(\mathrm{TiO}_{2}\right)$ desiccant wheel applied in East Asian climates. Sol. Energy 86, 1261-1279 (2012)

30. Zhang, Q., Tuzuka, T., Ishihara, N., Mclellan, B.C.: Integration of PV power into future low-carbon smart electricity systems with EV and HP in Kansai Area, Japan. Renew. Energy 44, 99-108 (2012)

31. Sendai City Gas Price: Sendai City Gas Bureau. Sendai City, Miyagi Prefecture, Japan. http://www.gas.city.sendai.jp/family/ charge/01/index.php\#oldplace. Accessed Sept 2015

32. $\mathrm{CO}_{2}$ : Specific carbon dioxide emissions of various fuels (2015). http://www.volker-quaschning.de/datserv/CO2-spez/index_e.php. Accessed: September 2014

33. Kerosene Fuel: Japan average gasoline price posts 6th straight weekly rise. http://www.forexlive.com/blog/2012/09/20/japanaverage-gasoline-price-posts-6th-straight-weekly-rise/. Accessed Oct 2014

34. Wood Chips: $20 \mathrm{~kg}$ (one bag) of quality of wood pellets (pellet stove fuel). http://global.rakuten.com/en/store/mitsuyoshi/item/ 537616/. Accessed Sept 2014
35. Natural Gas: Environmental emission of carbon dioxide $\mathrm{CO}_{2}$ when combustion fuels like coal, oil, natural gas, LPG and bio energy. http://www.engineeringtoolbox.com/co2-emission-fuelsd_1085.html. Accessed Sept 2014

36. Goto, H.: An empirical analysis on impact of time-of-use rate on household electric saving behaviour under power shortage and diffusion potential of time-of-use rate. In: Proceedings of 12th IAEE European Energy Conference, 11 Sept 2012 in University of Venice Ca' Foscari, Venice, Italy

37. Japan Electricity. Electricity in Japan: a year after Fukushima accident. http://dgr4energy.wordpress.com/2012/07/11/elec tricity-in-japan-a-year-after-fukushima-accident/. Accessed Aug 2014

38. AMeDAS: Automated Meteorological Data Acquisition System (AMeDAS). Japan Meteorological Agency (2015). http://www. jma.go.jp/jma/en/Activities/observations.html. Accessed Oct 2014

39. Homes: Homes that "leak" electricity, and how to plug them. http://www.lbl.gov/Science-Articles/Archive/leaking-watts.html. Accessed Sept 2014

40. Wong, P.W., Shimoda, Y., Nonaka, M., Inoue, M., Mizuno, M.: Semi-transparent PB: thermal performance, power generation, daylighting modeling and energy saving potential in a residential application. Renew. Energy 33, 1024-1036 (2008)

41. Liu, Q.R., Hayashi, T.: Effects of photovoltaics system introduction in detached houses with all-electrified houses residential equipment in Japan. World Acad. Sci. Eng. Technol. 19, 405-410 (2008)

42. Usami, Y., Yoshino, H., Sugawara, H.: Indoor environment and energy consumption pattern of an experimental house with energy efficient design. In: Proceedings of 6th International Conference on Indoor Air Quality, Ventilation and Energy Conservation in Buildings, 28-31 Oct 2007, Sendai, Japan

Napoleon Enteria is a Research Specialist of the Building Research Institute (BRI), Japan. He is a Visiting Researcher of the Faculty of Engineering, Tohoku University, Japan. He is the Founder and Managing Consultant of the Enteria Grün Energietechnik, Philippines. His research interests are in renewable energy systems, HVAC systems and building sciences.

Hiroshi Yoshino is a Professor Emeritus of the Tohoku University, Japan. Presently, he is the President of the Architectural Institute of Japan (AIJ). His research interests are in indoor environment and energy conservation in residential buildings, ventilation and indoor air quality, occupant's health and indoor environment and passive solar system performance.

Akira Satake is a Researcher of the Maeda Corporation. His research interests are in air-conditioning systems, ventilation systems and building sciences.

Rie Takaki is Assistant Professor of Akita Prefectural University. Her research interests are in indoor environment, ventilation systems and indoor air quality.

Hideki Ishihara is a Researcher of the Hokushu House Company. His research interests are in building sciences.

Seizo Baba is a Technical Researcher of the Earth Clean Tohoku Company. His technical interests are in desiccant air-conditioning systems. 